\title{
Solid-State Nuclear Magnetic Resonance Evidence for Parallel and Antiparallel Strand Arrangements in the Membrane-Associated HIV-1 Fusion Peptide ${ }^{\dagger}$
}

\author{
Jun Yang and David P. Weliky* \\ Department of Chemistry, Michigan State University, East Lansing, Michigan 48824
}

Received May 16, 2003; Revised Manuscript Received August 7, 2003

\begin{abstract}
The HIV-1 fusion peptide serves as a useful model system for understanding viral/target cell fusion, at least to the lipid-mixing stage. Previous solid-state NMR studies have shown that the membranebound HIV-1 fusion peptide adopts an extended conformation in a lipid mixture close to that of host cells of the virus. In the present study, solid-state NMR REDOR methods were applied for detection of oligomeric $\beta$ strand structure. The samples were prepared under fusogenic conditions and contained equimolar amounts of two peptides, one with selective $\left[{ }^{13} \mathrm{C}\right]$ carbonyl labeling and the other with selective $\left[{ }^{15} \mathrm{~N}\right]$ amide labeling. In the REDOR measurements, observation of reduced ${ }^{13} \mathrm{C}$ intensity due to hydrogen-bonded amide ${ }^{15} \mathrm{~N}$ provides strong experimental evidence of oligomer formation by the membrane-associated peptide. Comparison of REDOR spectra on samples that were labeled at different residue positions suggests that there are both parallel and antiparallel arrangements of peptide strands. In the parallel arrangement, interpeptide hydrogen bonding decreases toward the C-terminus, while in the antiparallel arrangement, hydrogen bonds are observed along the entire length of residues which was probed (Gly-5 to Gly-16). For the parallel arrangement, these observations are consistent with the model in which the apolar N-terminal and central regions of the peptides penetrate into the membrane and hydrogen bond with one another while the polar C-terminus of the peptide is outside the membrane and hydrogen bonds with water. These measurements show that, at least at the end state of fusion, the peptide can adopt an oligomeric $\beta$ strand structure.
\end{abstract}

Fusion between the membranes of enveloped viruses such as HIV $-1^{1}$ and influenza and the membranes of their target host cells is an essential step in infection $(1-4)$. For these viruses, this process is mediated by integral membrane viral envelope proteins which contain N-terminal $\sim 20$-residue apolar fusion peptide domains. For HIV-1 and influenza, the free fusion peptide has also been shown to be a useful model to understand fusion, at least to the lipid-mixing stage. The

\footnotetext{
$\doteqdot$ This work was supported in part by a Camille and Henry Dreyfus Foundation New Faculty Award, by NIH Award R01-AI47153, and by NSF Award 9977650 to D.P.W. A Michigan State University Center for Biological Modeling fellowship provided partial financial support for J.Y.

* To whom correspondence should be addressed. Telephone: 517355-9715. Fax: 517-353-1793. E-mail: weliky@cem.msu.edu.

${ }^{1}$ Abbreviations: CP, cross-polarization; CSA, chemical shift anisotropy; DPPC-1- ${ }^{13} \mathrm{C},\left[1-{ }^{13} \mathrm{C}\right]-1,2$-dipalmitoyl-sn-glycero-3-phosphocholine; ESR, electron spin resonance; FMOC, 9-fluorenylmethoxycarbonyl; FP, fusion peptide; HEPES, $N$-(2-hydroxyethyl)piperazine$N^{\prime}$-2-ethanesulfonic acid; HIV, human immunodeficiency virus, HPLC, high-performance liquid chromatography; LM, lipid mixture; LUV, large unilamellar vesicle; MAS, magic angle spinning; $M_{\mathrm{f}}$, final extent of lipid mixing; NMR, nuclear magnetic resonance; $N$-NBD-PE, $N$-(7nitro-2,1,3-benzoxadiazol-4-yl)phosphatidylethanolamine; $N$-Rh-PE, $N$ (lissamine rhodamine B sulfonyl)phosphatidylethanolamine; PDB, Protein Data Bank; PI, phosphatidylinositol; POPC, 1-palmitoyl-2oleoyl-sn-glycero-3-phosphocholine; POPE, 1-palmitoyl-2-oleoyl-snglycero-3-phosphoethanolamine; POPS, 1-palmitoyl-2-oleoyl-sn-glycero3-phospho-L-serine; rf, radio frequency; RET, resonance energy transfer; REDOR, rotational-echo double resonance; RFDR, radio frequencydriven dipolar recoupling; SEDRA, simple excitation for the dephasing of rotational-echo amplitudes; SIMPSON, simulation program for solidstate NMR spectroscopy; TFA, trifluoroacetic acid; TPPM, two pulse phase modulation; 1D, one dimensional; 2D, two dimensional.
}

free peptide causes fusion of liposomes and erythrocytes, and numerous mutational studies have shown strong correlations between fusion peptide-induced liposome fusion and viral/host cell fusion $(5-20)$. Recent studies suggest that envelope protein regions other than the fusion peptide also interact with membranes and play a role in fusion $(21-26)$.

There is a crystal structure of the part of the influenza hemagglutinin envelope protein which lies outside the virus and which contains the fusion peptide (27). This "ectodomain" structure corresponds to a prefusogenic conformation. For both the hemagglutinin and the HIV-1 gp41 envelope proteins, there are also atomic resolution structures of the "soluble ectodomains" which do not contain the fusion peptide $(28-34)$. These structures are believed to correspond to the protein conformations after fusion has occurred and perhaps during fusion as well. In each of these soluble ectodomain structures, the protein is trimeric, and its three $\mathrm{N}$-termini (corresponding to about residue 30 in the whole envelope protein) are in close proximity at the end of an in-register helical coiled-coil. These structures end several residues $\mathrm{C}$-terminal of the fusion peptide, and it has therefore been hypothesized that during viral/target cell fusion, at least three fusion peptides insert into the target cell membrane with their C-termini in close proximity.

A variety of experimental methods have shown that both the HIV-1 and influenza fusion peptides can assume helical or nonhelical structures in their membrane-associated forms $(6,9,10,14,15,17,18,35-50)$. Models for the helical structure have been developed on the basis of nuclear 
magnetic resonance (NMR), electron spin resonance (ESR), infrared, and circular dichroism data, as well as computer simulations $(51-56)$. Considerably less is known about the nonhelical peptide structures, but a $\beta$ hairpin model for the HIV-1 peptide has been proposed on the basis of the results of infrared, fluorescence, surface activity, and microscopy measurements $(57,58)$.

Fluorescence and ESR data also suggest that the nonhelical HIV-1 peptides form oligomeric structures $(16,20,35)$. The possible significance of fusion peptide oligomerization is suggested both by envelope protein trimerization and by experiments and modeling studies which indicate that the fusion site contains multiple trimers and a corresponding high fusion peptide concentration $(31,32,59-61)$. In addition, the functionally disruptive Val-2 to Glu-2 mutation in the gp41 fusion peptide is trans-dominant; i.e., cells expressing $10 \%$ mutant protein and $90 \%$ wild-type protein exhibit only $40 \%$ of the fusion activity of cells with $100 \%$ wild-type protein (8). One interpretation of these data is that the mutant peptide disrupts the correct assembly of a functionally important fusion peptide oligomer $(16,20)$.

Previous solid-state NMR studies on the HIV-1 fusion peptide demonstrated that the peptide adopts a predominantly $\beta$ strand structure when associated with membranes whose lipid headgroup and cholesterol composition is comparable to that found in host cells of the virus (45). One strength of the solid-state NMR approach is that membrane-associated peptide samples can be prepared under fusogenic conditions. In the present study, oligomeric structure in the membranebound HIV-1 fusion peptide was investigated using solidstate NMR methods which probe interpeptide hydrogen bonding. In these experiments, rotational-echo double resonance (REDOR) spectroscopy was applied to samples containing a 1:1 mixture of $\left[{ }^{13} \mathrm{C}\right]$ carbonyl-labeled peptide and $\left[{ }^{15} \mathrm{~N}\right]$ amide-labeled peptide. In the REDOR experiment, ${ }^{13} \mathrm{C}-{ }^{15} \mathrm{~N}$ dipolar couplings were measured and then related to $r_{\mathrm{CN}}$ distances and interpeptide hydrogen bonding through the $r^{-3}$ dependence of the dipolar coupling (62-72). In addition, the relative populations and structures of parallel and antiparallel strand arrangements in the oligomers were probed using a variety of samples which differed by the residue positions of the ${ }^{13} \mathrm{C}$ labeling in one peptide and/or the ${ }^{15} \mathrm{~N}$ labeling in the other peptide. The REDOR experiments demonstrate the presence of a large population of membrane-associated fusion peptide oligomers with approximately equal weighting of parallel and antiparallel strand arrangements.

\section{MATERIALS AND METHODS}

Materials. Rink amide resin was purchased from Advanced Chemtech (Louisville, KY), and 9-fluorenylmethoxycarbonyl (FMOC) amino acids were obtained from Peptides International (Louisville, KY). 1-Palmitoyl-2-oleoyl-sn-glycero-3phosphocholine (POPC), 1-palmitoyl-2-oleoyl-sn-glycero-3phosphoethanolamine (POPE), 1-palmitoyl-2-oleoyl-snglycero-3-phospho-L-serine (POPS), phosphatidylinositol (PI), sphingomyelin, $\left[1-{ }^{13} \mathrm{C}\right]-1,2$-dipalmitoyl-sn-glycero-3phosphocholine (DPPC-1- $\left.{ }^{13} \mathrm{C}\right), N$-(7-nitro-2,1,3-benzoxadiazol-4-yl)phosphatidylethanolamine (N-NBD-PE), $N$-(lissamine rhodamine B sulfonyl)phosphatidylethanolamine $(\mathrm{N}$ $\mathrm{Rh}-\mathrm{PE}$ ), and cholesterol were purchased from Avanti Polar
Lipids, Inc. (Alabaster, AL). The Micro BCA protein assay was obtained from Pierce (Rockford, IL). N-(2-Hydroxyethyl)piperazine- $N^{\prime}$-2-ethanesulfonic acid (HEPES) and Triton X-100 were obtained from Sigma. All other reagents were of analytical grade. The buffer solution used in the study contained $5 \mathrm{mM}$ HEPES ( $\mathrm{pH} 7.0$ ) with $0.01 \% \mathrm{NaN}_{3}$.

Peptides. FP peptides corresponding to the $23 \mathrm{~N}$-terminal residues (sequence AVGIGALFLGFLGAAGSTMGARS) of the LAV 1 a strain of HIV-1 gp41 were synthesized as their C-terminal amides using a peptide synthesizer (ABI 431A, Foster City, CA) equipped for FMOC chemistry. FP was either unlabeled (FP-unlabeled), triply $\left[{ }^{13} \mathrm{C}\right]$ carbonyl labeled at Phe-8, Leu-9, and Gly-10 [FP-(F8L9G10) C , triply $\left[{ }^{13} \mathrm{C}\right]-$ carbonyl labeled at Phe-11, Leu-12, and Gly-13 [FP$\left.(\mathrm{F} 11 \mathrm{~L} 12 \mathrm{G} 13)_{\mathrm{C}}\right]$, triply $\left[{ }^{15} \mathrm{~N}\right]$ amide labeled at Phe-8, Leu-9, and Gly-10 [FP-(F8L9G10) $\mathrm{N}]$, triply $\left[{ }^{15} \mathrm{~N}\right]$ amide labeled at Phe-11, Leu-12, and Gly-13 [FP-(F11L12G13) $)_{\mathrm{N}}$, or $\left[{ }^{13} \mathrm{C}\right]-$ carbonyl labeled at Phe-8 and $\left[{ }^{15} \mathrm{~N}\right]$ amide labeled at Leu-9 $\left(\mathrm{FP}-\mathrm{F} 8_{\mathrm{C}} \mathrm{L} 9_{\mathrm{N}}\right.$ ). FPK3 (sequence AVGIGALFLGFLGAAGSTMGARSKKK) was also synthesized as a more soluble FP analogue with three lysines added at the C-terminus (41). FPK3 was synthesized without labeling (FPK3-unlabeled) or triply $\left[{ }^{13} \mathrm{C}\right]$ carbonyl labeled at Gly-5, Ala-6, and Leu-7 [FPK3-(G5A6L7) $\mathrm{C}$, triply $\left[{ }^{13} \mathrm{C}\right]$ carbonyl labeled at Ala-14, Ala-15, and Gly-16 [FPK3-(A14A15G16) $]$, triply $\left[{ }^{15} \mathrm{~N}\right]-$ amide labeled at Gly-5, Ala-6, and Leu-7 [FPK3-(G5A6L7) $]$, triply $\left[{ }^{15} \mathrm{~N}\right]$ amide labeled Ala-14, Ala-15, and Gly-16 [FPK3$\left.(\mathrm{A} 14 \mathrm{~A} 15 \mathrm{G} 16)_{\mathrm{N}}\right]$, or $\left[{ }^{13} \mathrm{C}\right]$ carbonyl labeled at Phe-8 and $\left[{ }^{15} \mathrm{~N}\right]-$ amide labeled at Leu-9 (FPK3-F8 $\left.{ }_{\mathrm{C}} \mathrm{L} 9_{\mathrm{N}}\right)$.

As will be shown in the Results section, FP and FPK3 have comparable fusion activities and adopt similar membraneassociated structures. They are also both soluble at $\sim 100$ $\mu \mathrm{M}$ concentration in $5 \mathrm{mM}$ pH 7 HEPES buffer. In practical terms, the chief advantage of FPK 3 is that it dissolves more quickly in buffer than FP.

FPK3W-F8 ${ }_{\mathrm{C}} \mathrm{L} 9_{\mathrm{N}}$ (sequence AVGIGALFLGFLGAAGSTMGARSKKKW) was synthesized with a $\left[{ }^{13} \mathrm{C}\right]$ carbonyl label at Phe-8 and a $\left[{ }^{15} \mathrm{~N}\right]$ amide label at Leu-9. A 17-residue acetylated peptide $\mathrm{MB}(i+4) \mathrm{EK}-\mathrm{A} 9_{\mathrm{C}} \mathrm{A} 13_{\mathrm{N}}$ (sequence AcAEAAAKEAAAKEAAAKA) was synthesized as a Cterminal amide with $\left[{ }^{13} \mathrm{C}\right]$ carbonyl labeling at Ala-9 and $\left[{ }^{15} \mathrm{~N}\right]$ amide labeling at Ala-13. This peptide is predominantly $(\sim 85 \%) \alpha$ helical in its lyophilized form so the two labeled nuclei should have a $\mathrm{C}-\mathrm{N}$ internuclear distance of $\sim 4.1 \AA$ (73).

After synthesis, peptides were cleaved from the resin in a $3 \mathrm{~h}$ reaction using a mixture of TFA $-\mathrm{H}_{2} \mathrm{O}-$ phenolthioanisole-ethanedithiol in a 33:2:2:2:1 volume ratio. Peptides were subsequently purified by reversed-phase HPLC using a preparative $\mathrm{C}_{18}$ column (Vydac, Hesperia, CA) and a water-acetonitrile gradient containing $0.1 \%$ TFA. Mass spectroscopy was used for peptide identification.

For the labeled peptide syntheses, labeled amino acids were purchased from Icon Services Inc. (Summit, NJ) and were FMOC-protected using literature methods $(74,75)$. In addition, $\left[1-{ }^{13} \mathrm{C},{ }^{15} \mathrm{~N}\right]$ glycine and $\left[2-{ }^{13} \mathrm{C},{ }^{15} \mathrm{~N}\right]$ glycine samples were prepared by aqueous dissolution of a 1:9 mixture of labeled:unlabeled glycine followed by crystallization by slow evaporation of the water.

Lipid Preparation. Samples were prepared using lipid/ cholesterol mixtures reflecting the approximate lipid headgroup and cholesterol content of host cells of the virus (76). 
Two such mixtures were used: (a) "LM3" had POPC, POPE, POPS, sphingomyelin, PI, and cholesterol in a 10:5:2:2:1: 10 mole ratio; (b) "LM4" had DPPC- $1-{ }^{13} \mathrm{C}$, POPE, POPS, sphingomyelin, PI, and cholesterol in a 10:5:2:2:1:10 mole ratio. Thus, in $\mathrm{LM} 4,50 \%$ of the lipid molecules were $\left[{ }^{13} \mathrm{C}\right]-$ carbonyl labeled. Lipid and cholesterol powders were dissolved together in chloroform. The chloroform was removed under a stream of nitrogen followed by overnight vacuum pumping. Lipid dispersions were formed by addition of 5 $\mathrm{mM}$ pH 7.0 HEPES, followed by homogenization with 10 freeze-thaw cycles. Large unilamellar vesicles (LUVs) of $100 \mathrm{~nm}$ diameter were prepared by extrusion (77).

Lipid-Mixing Assay of Membrane Fusion. The resonance energy transfer (RET) assay was used to monitor membrane fusion (78). Two types of $100 \mathrm{~nm}$ diameter LM3 LUVs were prepared. One set contained $2 \mathrm{~mol} \%$ of the fluorescent lipid $N$-NBD-PE and $2 \mathrm{~mol} \%$ of the quenching lipid $N$-Rh-PE while the other set only contained unlabeled lipids. Fluorescently labeled and unlabeled vesicles were mixed in a 1:9 ratio. Following addition of the fusion peptide, lipid mixing between labeled and unlabeled vesicles caused dilution of the labeled lipids with a resulting increase of fluorescence. Fluorescence was recorded using $4 \mathrm{~nm}$ bandwidth on a Instruments S.A. Fluoromax-2 spectrofluorometer (Edison, NJ) operating at excitation and emission wavelengths of 465 and $530 \mathrm{~nm}$, respectively. A siliconized glass cuvette was used with continuous stirring in a thermostated cuvette holder. Measurements were carried out at $37^{\circ} \mathrm{C}$ with $2 \mathrm{~mL}$ of $150 \mu \mathrm{M}$ LUVs in buffer solution. The initial residual fluorescence intensity, $F_{0}$, referenced zero lipid mixing. After quantitation of the peptide concentrations with amino acid analysis, the requisite volume of $100 \mu \mathrm{M}$ FP or FPK3 peptide in $5 \mathrm{mM}$ pH 7.0 HEPES was added to achieve the desired peptide:lipid mole ratio, and the fluorescence $\left(F_{t}\right)$ of the sample was monitored as a function of time following this addition. The maximum fluorescence intensity, $F_{\max }$, was obtained following addition of $10 \mu \mathrm{L}$ of $20 \%$ Triton X-100. $F_{t}$ and $F_{\max }$ were corrected for the small fluorophore dilution resulting from the added volumes of peptide and Triton $\mathrm{X}-100$. Percent lipid mixing at time $t$ is denoted as $M_{t}$ and was calculated using

$$
M_{t}=\left[\left(F_{t}-F_{0}\right) /\left(F_{\max }-F_{0}\right)\right] \times 100
$$

With sufficient time, $M_{t}$ reached a constant value which is denoted as $M_{\mathrm{f}}$, the final extent of lipid mixing. $M_{\mathrm{f}}$ was used as an approximate measure of peptide fusogenicity. For a given set of labeled and unlabeled vesicles, $M_{\mathrm{f}}$ had $\pm 2 \%$ reproducibility between different assay trials.

Solid-State NMR Sample Preparation. Peptide was dissolved in $\sim 35 \mathrm{~mL}$ of $5 \mathrm{mM}$ HEPES, $\mathrm{pH}$ 7.0. Peptide concentrations were determined by the BCA assay which had been calibrated using quantitative amino acid analysis. For samples containing two differently labeled peptides, each peptide was dissolved separately and the two solutions were then combined. LUVs of LM3 or LM4 (40 $\mu$ mol of lipid + $20 \mu \mathrm{mol}$ of cholesterol) were prepared in $\sim 2 \mathrm{~mL}$ of buffer. The peptide and LUV solutions were then mixed and kept at room temperature overnight to ensure maximum peptide/ lipid binding. Subsequent ultracentrifugation of the solution at $100000 \mathrm{~g}$ for $4 \mathrm{~h}$ pelleted the membrane and associated bound peptide and left unbound peptide in the supernatant.
Peptide binding was typically quantitative as determined by BCA assay measurements of negligible peptide concentration in the supernatant. The peptide/lipid pellet formed after ultracentrifugation was transferred by spatula to a $6 \mathrm{~mm}$ diameter magic angle spinning (MAS) NMR rotor. In the absence of LUVs, FP did not pellet appreciably under the ultracentrifugation conditions (45).

Solid-State NMR Spectroscopy. Experiments were done on a 9.4 T spectrometer (Varian Infinity Plus) using a triple resonance MAS probe. The NMR detection channel was tuned to ${ }^{13} \mathrm{C}$ at $100.8 \mathrm{MHz}$, the decoupling channel was tuned to ${ }^{1} \mathrm{H}$ at $400.8 \mathrm{MHz}$, and the third channel was tuned to ${ }^{15} \mathrm{~N}$ at $40.6 \mathrm{MHz} .{ }^{13} \mathrm{C}$ and ${ }^{15} \mathrm{~N}$ chemical shifts were externally referenced to the methylene resonance of adamantane at 38.2 ppm and $\left(\mathrm{NH}_{4}\right)_{2} \mathrm{SO}_{4}$ at $20 \mathrm{ppm}$, respectively. Experiments used a MAS frequency of $8000 \pm 2 \mathrm{~Hz}$. In the NMR probe circuit, the radio frequency (rf) fields are highly attenuated at the ends of the coil, and it was experimentally observed that nearly all of the NMR signal comes from the central two-third coil volume. Hence, for the FPK3 samples, longer spacers were used to restrict samples to this central volume $(\sim 160 \mu \mathrm{L})$. For the other samples, the full volume of the rotor was used. Because the outer one-third volume contributes negligible signal, direct comparison could be made between all of the samples. The chief advantage of the volume restriction is lower sample requirement.

The experiments were performed at $-50{ }^{\circ} \mathrm{C}$ because, relative to room temperature, there is about three times greater signal per ${ }^{13} \mathrm{C}$ at the lower temperature. This result is likely in part due to more efficient cross-polarization (CP) because of reduced motion at lower temperature. ${ }^{13} \mathrm{C}$ backbone chemical shifts were similar at both temperatures, which suggests that cooling the sample does not cause significant peptide structural changes (50).

In REDOR experiments to detect hydrogen bonds, between 1 and $2 \mathrm{~ms}$ of $\mathrm{CP}$ at $50 \mathrm{kHz}$ was followed by a $24.0 \mathrm{~ms}$ dephasing period and then direct ${ }^{13} \mathrm{C}$ detection (62). A single $50 \mathrm{kHz}{ }^{13} \mathrm{C}$ refocusing $\pi$ pulse was placed at the center of the dephasing period, and ${ }^{1} \mathrm{H}$ TPPM decoupling of $65 \mathrm{kHz}$ was applied during both dephasing and detection (79). The ${ }^{13} \mathrm{C}$ transmitter was set to $155 \mathrm{ppm}$, and the ${ }^{15} \mathrm{~N}$ transmitter was set to $115 \mathrm{ppm}$. For the $S_{1}$ acquisition, the dephasing period contained a $40 \mathrm{kHz}{ }^{15} \mathrm{~N} \pi$ pulse at the middle and end of each rotor cycle, while the $S_{0}$ acquisition did not contain these pulses. XY-8 phase cycling was used for the ${ }^{15} \mathrm{~N}$ pulses $(80,81)$. This "all ${ }^{15} \mathrm{~N} \pi$ pulse" version of REDOR was used for most of the experiments, but in some preliminary experiments, a different "alternating ${ }^{15} \mathrm{~N} /{ }^{13} \mathrm{C} \pi$ pulse" version of REDOR was employed in which one ${ }^{15} \mathrm{~N}$ and one ${ }^{13} \mathrm{C} \pi$ pulse were applied per rotor cycle during the dephasing period $(63,82)$. For both REDOR versions, the difference between the $S_{0}$ and $S_{1}$ signal intensities is known as "dephasing" and is the experimental parameter used to determine ${ }^{13} \mathrm{C}-{ }^{15} \mathrm{~N}$ dipolar couplings and distances.

The spectrometer parameters were optimized with the lyophilized $\mathrm{MB}(i+4) \mathrm{EK}-\mathrm{A} 9_{\mathrm{C}} \mathrm{A} 13_{\mathrm{N}}$ model helical peptide. Calibration of the ${ }^{13} \mathrm{C} \pi$ pulse length was done with a " $\mathrm{Z}$ filter" sequence $(\mathrm{CP}-\pi / 2-\tau-\pi-$ acquire $)$ in which ${ }^{1} \mathrm{H}$ decoupling was applied during the pulses and acquisition and for $10 \mu \mathrm{s}$ at the beginning and end of the $\tau$ period. The ${ }^{15} \mathrm{~N} \pi$ pulse was calibrated with minimization of the $S_{1}$ REDOR signal at $24.0 \mathrm{~ms}$ dephasing time. REDOR signals 
for the $\mathrm{MB}(i+4) \mathrm{EK}-\mathrm{A} 9_{\mathrm{C}} \mathrm{A} 13_{\mathrm{N}}$ peptide were similar with or without active synchronization of the pulses to the rotor phase, and for the HIV-1 fusion peptide samples, pulses were not actively synchronized to the rotor phase. To obtain optimal compensation of $B_{0}, B_{1}$, and spinning frequency drifts, $S_{0}$ and $S_{1}$ FIDs were acquired alternately. The recycle delay was $1 \mathrm{~s}$. The data were processed with $100 \mathrm{~Hz}$ line broadening and with fifth-order polynomial baseline correction.

For experiments designed to measure the Phe- 8 carbonyl chemical shift of the LM3-associated FP-F8 ${ }_{\mathrm{C}} \mathrm{L} 9_{\mathrm{N}}$ and FPK3$\mathrm{F} 8_{\mathrm{C}} \mathrm{L} 9_{\mathrm{N}}$ peptides, NMR spectra were taken using a REDOR filter of the directly bonded ${ }^{13} \mathrm{C}-{ }^{15} \mathrm{~N}$ dipolar interaction so that the Phe- 8 carbonyl was the only signal observed in the ${ }^{13} \mathrm{C}$-detected REDOR difference spectrum (48). The experimental settings were similar to those of the previously described hydrogen bond REDOR experiments except that the dephasing time was set to $1.0 \mathrm{~ms}$ and a difference FID was obtained from $S_{0}-S_{1}$. The difference FID was processed with $50 \mathrm{~Hz}$ line broadening and with fifth-order polynomial baseline correction.

REDOR Data Analysis and Simulations. For the REDOR experiments designed to detect interpeptide hydrogen bonding, integration of signal intensities in the isotropic carbonyl regions of the $S_{0}$ and $S_{1}$ spectra yielded values which are denoted as " $S_{0}$ " and " $S_{1}$ ". $\Delta S / S_{0}$ is a convenient normalized dephasing parameter for comparison of experiment and simulation and is defined as

$$
\Delta S / S_{0}=\left(S_{0}-S_{1}\right) / S_{0}=1-\left(S_{1} / S_{0}\right)
$$

In addition, for each pair of $S_{0} / S_{1}$ spectra, an experimental uncertainty $\sigma$ was calculated as the root mean squared deviation of integrated intensities in 24 regions of the spectra without signal. $\sigma_{\Delta S / S_{0}}$, the uncertainty in $\Delta S / S_{0}$, was calculated using the formula (83)

$$
\sigma_{\Delta S / S_{0}}=\sigma\left(S_{1} / S_{0}\right) \sqrt{\left(1 / S_{0}\right)^{2}+\left(1 / S_{1}\right)^{2}}
$$

Simulations of the REDOR experiment were carried out as a function of peptide structure and dephasing period using the SIMPSON program (84). The experimental pulse sequence, MAS frequency, ${ }^{13} \mathrm{C}$ and ${ }^{15} \mathrm{~N}$ rf fields and pulse lengths, and ${ }^{15} \mathrm{~N}$ phases were incorporated into the simulations. Carbonyl chemical shift anisotropy (CSA) principal values were set to be 250,190, and 90 ppm, and the principal axis directions were taken from the literature with the following orientations: $\delta_{33}$ perpendicular to the peptide plane and $\delta_{22}$ at an angle $\chi=130^{\circ}$ from the $\mathrm{C}-\mathrm{N}$ bond (85). The calculated REDOR dephasing curves were approximately independent of the carbonyl CSA principal axis geometry, which is consistent with simulations in other studies (86). ${ }^{1} \mathrm{H}$ were not considered in the simulations. For each simulation of a sample containing adjacent ${ }^{13} \mathrm{C}$ and ${ }^{15} \mathrm{~N}$ triply labeled strands, either a parallel or antiparallel $\beta$ sheet geometry was assumed and was based on coordinates obtained from the crystal structure of the B1 domain of streptococcal protein G (PDB file 1igd) (87). Each simulation also used a defined register of the ${ }^{13} \mathrm{C}$ - and ${ }^{15} \mathrm{~N}$-labeled residues in neighboring strands.
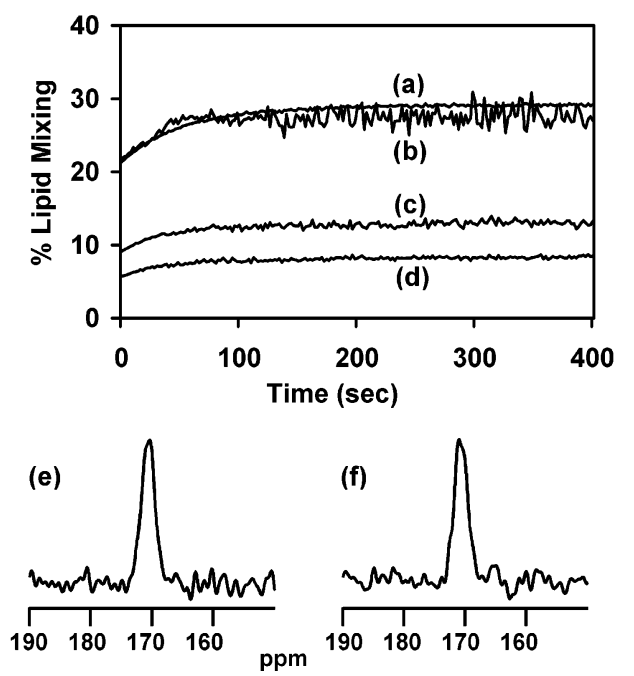

FIGURE 1: Lipid mixing induced by FP and FPK3 (top) and REDOR-filtered $S_{0}-S_{1}$ difference spectra of FP and FPK3 samples (bottom). For the lipid-mixing assay, $150 \mu \mathrm{M}$ LM3 lipid was extruded into $100 \mathrm{~nm}$ diameter vesicles. Lipid mixing was induced with (a) $3 \mu \mathrm{M}$ and (d) $1.5 \mu \mathrm{M}$ FPK3 and (b) $3 \mu \mathrm{M}$ and (c) $1.5 \mu \mathrm{M}$ FP. The same set of vesicles was used for all measurements. The (e) $\mathrm{FP}-\mathrm{F} 8_{\mathrm{C}} \mathrm{L} 9_{\mathrm{N}}$ and (f) FPK3-F8 ${ }_{\mathrm{C}} \mathrm{L} 9_{\mathrm{N}}$ samples contained $\sim 0.3 \mu \mathrm{mol}$ of peptide which was $\left[{ }^{13} \mathrm{C}\right]$ carbonyl labeled at Phe- 8 and ${ }^{15} \mathrm{~N}$-labeled at Leu-9 as well as LM3 (40 $\mu \mathrm{mol}$ of lipid and $20 \mu \mathrm{mol}$ of cholesterol). The Phe- 8 carbonyl signal dominates the difference spectrum. Each spectrum was processed with $50 \mathrm{~Hz}$ line broadening and represented the result of $\sim 22000$ total $\left(S_{0}+S_{1}\right)$ scans. The data were acquired at $-50{ }^{\circ} \mathrm{C}$ using $8 \mathrm{kHz}$ MAS frequency. ${ }^{1} \mathrm{H}$ TPPM decoupling at $65 \mathrm{kHz}$ was applied during the $1.0 \mathrm{~ms}$ dephasing period and during acquisition. These data show that the fusogenicities and local structures of the two peptides are comparable.

\section{RESULTS}

Similarity of FP, FPK3, and FPK3W. For the influenza fusion peptide, addition of a lysine-rich "host sequence" at the C-terminus of the peptide improves the peptide solubility in aqueous solution $(41,88)$. For some of our solid-state NMR samples, a similar modification was made for the HIV-1 fusion peptide (FPK3), and we wanted to establish that this addition did not have a significant effect on the peptide interaction with membranes. Lipid-mixing assays were carried out to assess peptide fusogenicities, and solidstate NMR measurements were used to probe local structure in the centers of the membrane-associated peptides.

Figure $1 \mathrm{a}-\mathrm{d}$ displays the results of the lipid-mixing assays. In general, FP and FPK3 show comparable $M_{\mathrm{f}}$, with FP somewhat higher at peptide:lipid $=0.01$ and the two peptides approximately equal at peptide:lipid $=0.02$. Local structure was examined through comparison of the Phe- 8 carbonyl NMR spectra of the LM3-associated peptides at peptide:lipid $=0.008$ (cf. Figure 1e,f). Because of the directly bonded ${ }^{13} \mathrm{C}-{ }^{15} \mathrm{~N}$ spin pairs in $\mathrm{FP}-\mathrm{F} 8_{\mathrm{C}} \mathrm{L} 9_{\mathrm{N}}$ and $\mathrm{FPK} 3-\mathrm{F} 8_{\mathrm{C}} \mathrm{L} 9_{\mathrm{N}}$, the Phe- 8 carbonyl signals dominate the displayed REDORfiltered difference spectra, with quantitative attenuation of the natural abundance ${ }^{13} \mathrm{C}$ signals from lipid and peptide. In both spectra, the full-width at half-maximum line widths are $\sim 2.5 \mathrm{ppm}$, which is consistent with a relatively narrow conformational distribution at Phe- 8 , and the peak chemical shifts are $\sim 171 \mathrm{ppm}$, which is consistent with nonhelical local structure (89-93). The overall similarity of the lipidmixing data and NMR spectra for FP and FPK3 suggests that both peptides have comparable interactions with LM3 
membranes. We note that previous solid-state NMR chemical shift and 2D exchange studies for LM3-associated FP were consistent with $\beta$ strand structure at other residues in the peptide as well (45).

Lipid-mixing and NMR studies were carried out on FPK $3 \mathrm{~W}-\mathrm{F} 8_{\mathrm{C}} \mathrm{L} 9_{\mathrm{N}}$ in LM3 and produced results similar to those shown in Figure 1. In addition, analytical ultracentrifugation measurements demonstrated that a $90 \mu \mathrm{M}$ solution of FPK3W in $5 \mathrm{mM}$ HEPES, $\mathrm{pH} 7.0$, is predominantly monomeric (data not shown). This result suggests that FPK3 is also a monomer in solution at the $10-60 \mu \mathrm{M}$ concentrations used for preparation of solid-state NMR samples in the present study. Demonstration of monomeric behavior in solution is significant because it establishes that membranebound oligomers can be the result of peptide interactions at the membrane surface or in the membrane interior. The membrane-bound oligomers do not simply reflect the membrane deposition of oligomers which preexisted in aqueous solution.

Choice of REDOR Experiments. REDOR is a widely used solid-state NMR technique to probe heteronuclear dipolar couplings and distances (70). In this study, REDOR was applied to identify interpeptide hydrogen bonding through detection of the $40-45 \mathrm{~Hz}{ }^{13} \mathrm{C}-{ }^{15} \mathrm{~N}$ dipolar coupling arising from an $\sim 4.1 \AA\left[{ }^{13} \mathrm{C}\right]$ carbonyl- $\left[{ }^{15} \mathrm{~N}\right]$ amide distance. For the REDOR experiment, this is a rather weak coupling whose detection requires a dephasing period of $10-30 \mathrm{~ms}$ duration and hundreds of NMR $\pi$ pulses. We therefore expended some effort in optimizing the REDOR experiment for detection of these hydrogen bonds. The main compound used for optimization was the lyophilized model helical peptide MB$(i+4) \mathrm{EK}-\mathrm{A} 99_{\mathrm{C}} \mathrm{A} 13_{\mathrm{N}}$.

The REDOR experiment relies on application of two $\pi$ pulses per rotor cycle, and these could be both ${ }^{13} \mathrm{C}$ pulses or both ${ }^{15} \mathrm{~N}$ pulses (all ${ }^{15} \mathrm{~N} \pi$ pulse version) or one ${ }^{15} \mathrm{~N}$ and one ${ }^{13} \mathrm{C}$ pulse (alternating ${ }^{15} \mathrm{~N} /{ }^{13} \mathrm{C} \pi$ pulse version). When the alternating ${ }^{15} \mathrm{~N} /{ }^{13} \mathrm{C} \pi$ pulse version of REDOR was applied to polycrystalline $\left[1-{ }^{13} \mathrm{C},{ }^{15} \mathrm{~N}\right]$ glycine and $\left[2-{ }^{13} \mathrm{C},{ }^{15} \mathrm{~N}\right]$ glycine samples, the experimental $\Delta S / S_{0}$ values as a function of dephasing period fit well to simulations. When this version of REDOR was applied to the $\mathrm{MB}(i+4) \mathrm{EK}-\mathrm{A} 9_{\mathrm{C}} \mathrm{A} 13_{\mathrm{N}}$ peptide, the experimental $\Delta S / S_{0}$ values could also be fit well to simulations based on a structurally reasonable $4.1 \AA{ }^{13} \mathrm{C}-$ ${ }^{15} \mathrm{~N}$ distance. Prior to fitting, the experimental $\Delta S / S_{0}$ values were multiplied by a correction factor of magnitude $1.2-$ 1.3 , which accounted for the $\sim 15 \%$ population of random coil peptide in the sample, the small populations of labeled and natural abundance carbonyls which experience complete dephasing from neighboring natural abundance ${ }^{15} \mathrm{~N}$ and labeled ${ }^{15} \mathrm{~N}$, respectively, and the remaining population of natural abundance carbonyls which do not dephase.

When the all ${ }^{15} \mathrm{~N} \pi$ pulse version of REDOR was applied to the $\mathrm{MB}(i+4) \mathrm{EK}-\mathrm{A} 9_{\mathrm{C}} \mathrm{A} 13_{\mathrm{N}}$ peptide, the corrected $\Delta S / S_{0}$ values were less than those predicted by simulation. Variation of experimental parameters such as ${ }^{15} \mathrm{~N}$ pulse shape did not have a significant impact on the experimental data. However, when the REDOR experiment was done in a $4 \mathrm{~mm}$ probe with $100 \mathrm{kHz}$ TPPM ${ }^{1} \mathrm{H}$ decoupling, the data agreed much better with simulation. Reduction of decoupling to $70 \mathrm{kHz}$ in the $4 \mathrm{~mm}$ probe gave $\Delta S / S_{0}$ which was comparable to that found for the $6 \mathrm{~mm}$ probe with $65 \mathrm{kHz}$ decoupling. Because $\Delta S / S_{0}$ represents a normalized difference between FIDs with the same ${ }^{1} \mathrm{H}$ decoupling, it is not obvious why ${ }^{1} \mathrm{H}$

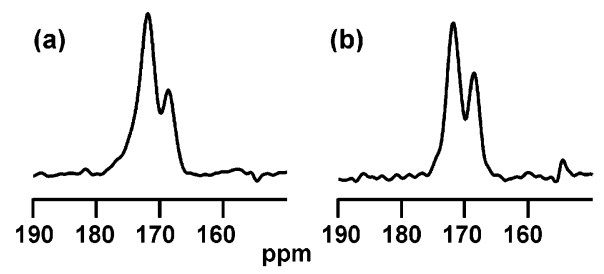

FIGURE 2: ${ }^{13} \mathrm{C}$ solid-state NMR spectra of the FPK3-(G5A6L7) $)_{\mathrm{C}}$ FPK3-(14A15A16G) $)_{N} / \mathrm{LM} 3$ sample from the (a) CP experiment and (b) $S_{0}$ REDOR experiment with a $24.0 \mathrm{~ms}$ dephasing time. Each spectrum was processed with $100 \mathrm{~Hz}$ line broadening, and the spectral intensities in each experiment were divided by the number of scans in that experiment. The vertical scale in (b) is 8 times that in (a), showing that the signal/scan in (b) is $\sim 1 / 8$ as large as that in (a). The spectrum in (b) appears better resolved than the spectrum in (a) because the natural abundance lipid carbonyls make a relatively smaller contribution to the $S_{0}$ signal than to the $\mathrm{CP}$ signal.

decoupling should affect $\Delta S / S_{0}$, but we note that there has been some controversy in the literature about the impact of ${ }^{1} \mathrm{H}$ decoupling and the ratio of ${ }^{1} \mathrm{H}$ to ${ }^{15} \mathrm{~N}$ fields in REDOR and other dipolar recoupling experiments (94-99).

As displayed in Figure 2, sensitivity was also an important factor in the REDOR experiment. For the all ${ }^{15} \mathrm{~N} \pi$ pulse version of REDOR on a sample containing triply carbonyllabeled peptide, the $S_{0}$ signal at $24.0 \mathrm{~ms}$ dephasing time was about one-eighth that obtained with direct CP. With the alternating ${ }^{13} \mathrm{C} /{ }^{15} \mathrm{~N} \pi$ pulse version of REDOR, there was additional attenuation by a factor of $\sim 0.6$, which may be a result of $\pi$ pulse SEDRA/RFDR recoupling of ${ }^{13} \mathrm{C}-{ }^{13} \mathrm{C}$ homonuclear interactions (100-102). In our study, REDOR was used as a semiquantitative probe of the extent of hydrogen bonding, and we chose to use the higher signalto-noise all ${ }^{15} \mathrm{~N} \pi$ pulse version of REDOR. In general, as the dephasing period increases, $\Delta S / S_{0}$ also increases, whereas the overall signal decreases. The chosen $24.0 \mathrm{~ms}$ dephasing period represents a compromise between these two competing effects.

REDOR Calibration and Control Experiments. Table 1 lists $\Delta S / S_{0}$ values from a series of REDOR calibration and control experiments, and Figure 3 displays some of the corresponding experimental spectra. In our discussion of these results, " $13 \mathrm{C}$ " and " $15 \mathrm{~N}$ " refer specifically to carbonyl carbons and amide nitrogens, respectively. The goal of the first experiment was calibration of $\Delta S / S_{0}$ due to a $4.1 \AA^{13} \mathrm{C}-$ ${ }^{15} \mathrm{~N}$ hydrogen-bonded pair. Using data from the lyophilized $\alpha$ helical MB $(i+4)$ EK-A9 ${ }_{\mathrm{C}} \mathrm{A} 13_{\mathrm{N}}$ peptide (cf. Figure $3 \mathrm{a}$ ), this value was estimated to be $0.45-0.50$. This estimation included corrections for the small population of random coil peptide in the sample and the dephasing of natural abundance ${ }^{13} \mathrm{C}$.

The goal of the remaining control experiments was to quantitate $\left(\Delta S / S_{0}\right)_{\text {background, }}$ which represents dephasing in the membrane-associated peptide samples which was not due to the labeled ${ }^{13} \mathrm{C}-{ }^{15} \mathrm{~N}$ hydrogen-bonded pairs. For samples containing only ${ }^{13} \mathrm{C}$-labeled and/or natural abundance peptide (cf. Figure $3 b, d$ ), the $\Delta S / S_{0}$ value is in the -0.01 to 0.03 range and is due to the $0.0037 \%{ }^{15} \mathrm{~N}$ natural abundance and the resulting small population of carbonyls with nearby ${ }^{15} \mathrm{~N}$. For example, a ${ }^{13} \mathrm{C}$ with ${ }^{15} \mathrm{~N}$ one or two bonds away on the peptide backbone will have an individual $\Delta S / S_{0} \approx 1$ at 24.0 ms dephasing time. For a sample containing a 1:1 mixture of ${ }^{15} \mathrm{~N}$-labeled and unlabeled peptide (cf. Figure $3 \mathrm{c}$ ), $\Delta S / S_{0}$ $\sim 0.2$, while for a sample containing only ${ }^{15} \mathrm{~N}$-labeled 
Table 1: REDOR Calibration and Control Experiments ${ }^{a}$

\begin{tabular}{|c|c|c|}
\hline sample $^{b}$ & $\Delta S / S_{0}{ }^{c}$ & figure \\
\hline $\mathrm{MB}(i+4) \mathrm{EK}-\mathrm{A} 9_{\mathrm{C}} \mathrm{A} 13_{\mathrm{N}}$ & $0.38(0.01)$ & $3 a$ \\
\hline FP-(F8L9G10) $/$ /FP unlabeled/LM3 & $0.01(0.01)$ & $3 b$ \\
\hline FP-(F8L9G10) $/$ FP unlabeled/LM3 & $0.20(0.05)$ & $3 \mathrm{c}$ \\
\hline FPK3 unlabeled/LM3 & $-0.01(0.06)$ & $3 d$ \\
\hline FP-(F8L9G10) $/$ /LM4 & $0.03(0.02)$ & $3 e$ \\
\hline FP-(F8L9G10) $/$ LM3 & $0.41(0.05)$ & $\mathrm{ns}^{d}$ \\
\hline FP unlabeled/LM4 & $0.01(0.03)$ & ns \\
\hline FP-(F11L12G13) & $0.03(0.02)$ & ns \\
\hline FPK3-(A14A15G16) $)_{\mathrm{N}}$ & $0.35(0.02)$ & ns \\
\hline FPK3 unlabeled & $0.00(0.02)$ & $\mathrm{ns}$ \\
\hline
\end{tabular}

${ }^{a}$ The dephasing time was $24.0 \mathrm{~ms} .{ }^{b}$ Samples with LM3 or LM4 contained peptide bound to hydrated membranes. All other samples were lyophilized dry peptide. For membrane-associated peptide samples, the overall peptide:lipid mole ratio was $\sim 0.04$, and for samples containing two peptides, the peptide:peptide mole ratio was $\sim 1 .{ }^{c}$ The uncertainty is enclosed in parentheses. ${ }^{d}$ Not shown in a figure.

peptide, $\Delta S / S_{0} \sim 0.4$. These relatively large $\Delta S / S_{0}$ values are likely a result of the significant fraction of natural abundance carbonyls which are close to the labeled ${ }^{15} \mathrm{~N}$. For the samples used to probe fusion peptide strand arrangements, there was a $1: 1$ mixture of ${ }^{13} \mathrm{C}$ - and ${ }^{15} \mathrm{~N}$-labeled peptides and an $\sim 10 \%$ natural abundance peptide contribution to the total ${ }^{13} \mathrm{C}$ signal. In these samples, we would therefore expect an $\sim 0.02$ contribution to $\Delta S / S_{0}$ from natural abundance peptide ${ }^{13} \mathrm{C}$.

In samples containing $50 \%\left[{ }^{13} \mathrm{C}\right]$ carbonyl-labeled lipid (LM4) and either ${ }^{15} \mathrm{~N}$-labeled peptide or unlabeled peptide, $\Delta S / S_{0} \sim 0.03$ or 0.01 , respectively (cf. Figure 3e). In addition, when CP and $S_{0}$ intensities of these samples were compared to those of samples containing unlabeled lipid and ${ }^{13} \mathrm{C}$-labeled peptide, it was observed that the $\mathrm{CP}$ signal per ${ }^{13} \mathrm{C}$ is about three times less for a lipid carbonyl than for a peptide carbonyl while the $S_{0}$ signal per ${ }^{13} \mathrm{C}$ is about nine times less for a lipid carbonyl than for a peptide carbonyl. By combining this latter result with the observation that $\Delta S / S_{0}$ $\sim 0.4$ for the sample containing unlabeled lipid and ${ }^{15} \mathrm{~N}$ labeled peptide, it is possible to account for the $\Delta S / S_{0}$ values in the $\left[{ }^{13} \mathrm{C}\right]$ lipid-labeled samples by only considering dephasing of the natural abundance peptide carbonyl signal. This analysis suggests negligible dephasing of the lipid carbonyls.

The overall conclusion of the control experiments is that $\left(\Delta S / S_{0}\right)_{\text {background }} \sim 0.03$ for the LM3 samples with a $1: 1$ mixture of labeled ${ }^{13} \mathrm{C}$ and ${ }^{15} \mathrm{~N}$ peptides. This $\left(\Delta S / S_{0}\right)_{\text {background }}$ value is $\sim 2 / 3$ due to dephasing of natural abundance peptide carbonyl by labeled ${ }^{15} \mathrm{~N}$ and $\sim 1 / 3$ due to dephasing of labeled peptide carbonyl by natural abundance ${ }^{15} \mathrm{~N}$. The contribution of the lipid carbonyl to $\left(\Delta S / S_{0}\right)_{\text {background }}$ is negligible.

REDOR Experiments To Probe Interpeptide Hydrogen Bonding. Figure 4 displays the $S_{0}$ and $S_{1}$ REDOR spectra of membrane-associated fusion peptide samples, and the associated $\Delta S / S_{0}$ values are listed in Table 2. Each sample was made with the LM3 lipid mixture ( $40 \mu \mathrm{mol}$ of lipid and 20 $\mu \mathrm{mol}$ of cholesterol), $\sim 0.8 \mu \mathrm{mol}$ of peptide with selective $\left[{ }^{13} \mathrm{C}\right]$ carbonyl labeling, and $\sim 0.8 \mu \mathrm{mol}$ of peptide with selective $\left[{ }^{15} \mathrm{~N}\right]$ amide labeling.

Four samples (cf. Figure $4 \mathrm{a}-\mathrm{d}$ ) were prepared to probe for the presence of an approximate in-register parallel arrangement of peptide strands. In each of these samples, the labeling in the ${ }^{13} \mathrm{C}$ peptide and in the ${ }^{15} \mathrm{~N}$ peptide was at the same set of three sequential residues. With these four samples, interstrand hydrogen bonding of parallel strands was probed between Gly-5 and Gly-16. For the samples labeled
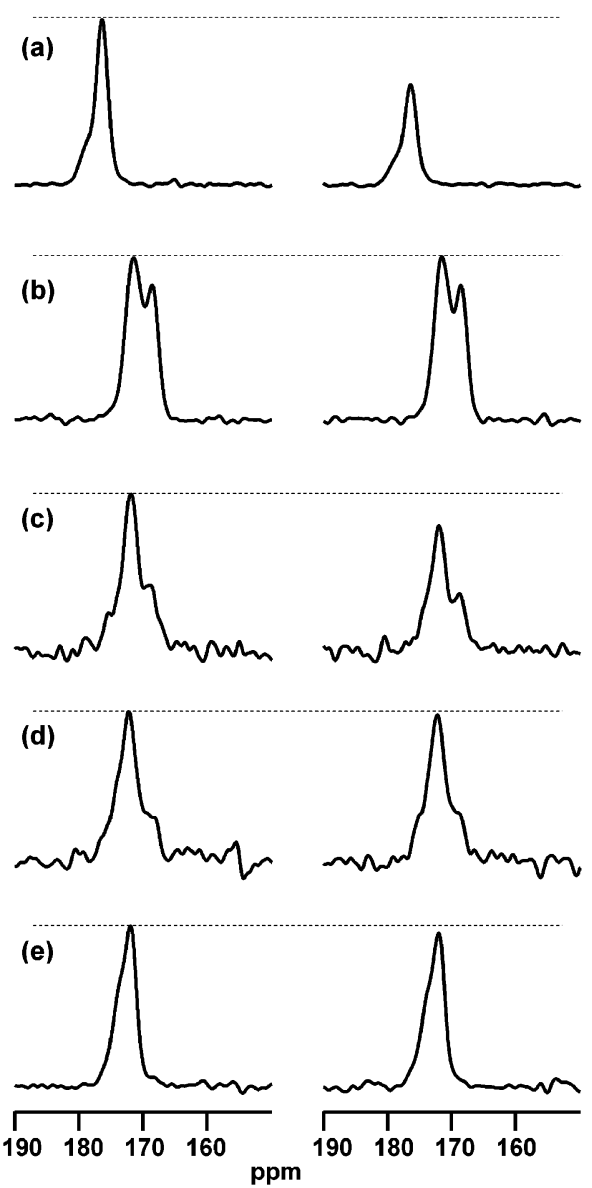

FIGURE 3: ${ }^{13} \mathrm{C}$ solid-state NMR REDOR calibration and control experiments of the (a) lyophilized MB $(i+4)$ EK-A $9{ }_{\mathrm{C}} \mathrm{A} 13_{\mathrm{N}}$ model helical peptide and membrane-associated fusion peptides that had (b) $\sim 0.8 \mu \mathrm{mol}$ each of FP-(F8L9G10) ${ }_{\mathrm{C}}$ and FP-unlabeled, (c) $\sim 0.8$ $\mu$ mol each of FP-(F8L9G10) $)_{\mathrm{N}}$ and FP-unlabeled, (d) $\sim 1.6 \mu \mathrm{mol}$ of FPK3-unlabeled, and (e) $\sim 1.6 \mu \mathrm{mol}$ of FP-(F8L9G10) . Each of the samples in $(\mathrm{b}-\mathrm{e})$ also contained $40 \mu \mathrm{mol}$ of lipid and $20 \mu \mathrm{mol}$ of cholesterol. For samples in $(b-d)$, the LM3 lipid mixture was used, and for the sample in (e), the LM4 lipid mixture was used. In LM3, $50 \mathrm{~mol} \%$ of the lipid was unlabeled POPC, whereas in LM4, the POPC was replaced with $\left[{ }^{13} \mathrm{C}\right]$ carbonyl-labeled DPPC. In $(\mathrm{a}-\mathrm{e})$, the $S_{0}$ spectrum is on the left and the $S_{1}$ spectrum is on the right, and the spectra were acquired without and with ${ }^{15} \mathrm{~N} \pi$ pulses during the dephasing period, respectively. The dotted lines are included for visual comparison of the spectral intensities. These measurements were taken under the same conditions as described in Figure 1 except that the dephasing period was $24.0 \mathrm{~ms}$ and the number of scans for each spectrum $\left(S_{0}\right.$ or $\left.S_{1}\right)$ was 256,104352 , 283024,272000 , and 85808 in $(\mathrm{a}-\mathrm{e})$, respectively.

between Gly-5 and Gly-13, the $\Delta S / S_{0}$ values were in the $0.11-0.13$ range, which is significantly above the 0.03 background value. For the sample containing peptide labeled between Ala-14 and Gly-16, $\Delta S / S_{0} \sim 0.03$, which is the approximate background signal. Thus, it appears that there is a population of peptides with parallel arrangements of strands, and this arrangement frays apart toward the Cterminal side of the peptide. These results are schematically presented in Figure 5a and are consistent with a reasonable biophysical model based on the peptide sequence. In the sequence, the N-terminal and central regions only contain apolar residues while the C-terminal region contains a substantial fraction of polar or charged residues. For extended peptides in an oligomeric parallel strand arrangement, the apolar regions of all strands would be on one end of the oligomer and the polar regions would be on the other end 

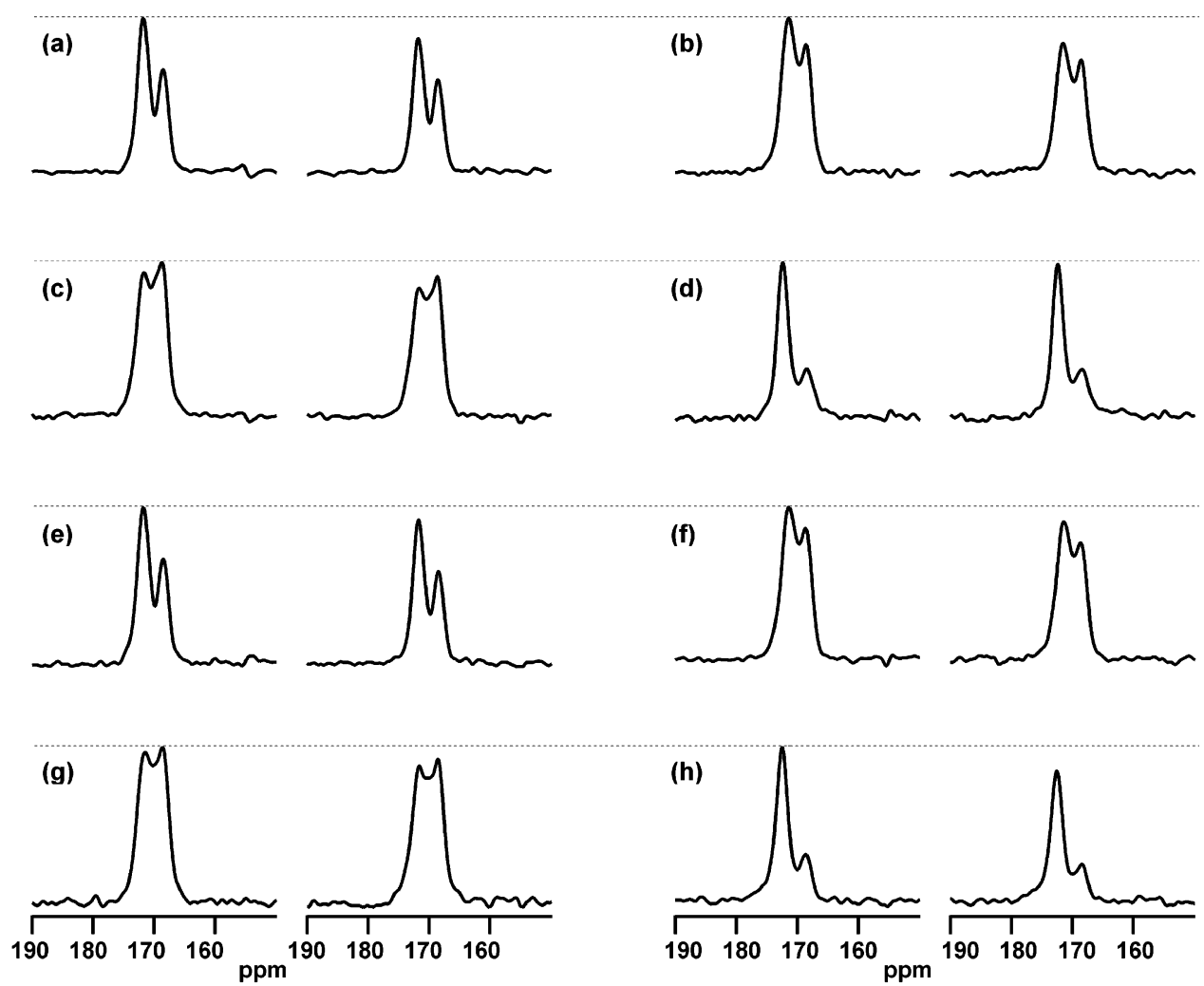

FIGURE 4: ${ }^{13} \mathrm{C}$ solid-state NMR $S_{0}$ and $S_{1}$ REDOR spectra of membrane-associated fusion peptides. Each sample was made with the LM3 lipid mixture (40 $\mu \mathrm{mol}$ of lipid and $20 \mu \mathrm{mol}$ of cholesterol), $\sim 0.8 \mu \mathrm{mol}$ of peptide with selective $\left[{ }^{13} \mathrm{C}\right]$ carbonyl labeling, and $\sim 0.8 \mu \mathrm{mol}$ of peptide with selective $\left[{ }^{15} \mathrm{~N}\right]$ amide labeling. The specific labeling schemes were (a) FPK3-(G5A6L7) $/$ FPK3-(G5A6L7) $)_{\mathrm{N}}$, (b) FP-(F8L9G10) $/$

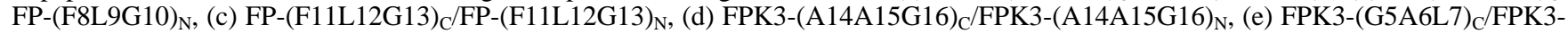
$(\mathrm{A} 14 \mathrm{~A} 15 \mathrm{G} 16)_{\mathrm{N}}$, (f) FP-(F8L9G10) $\mathrm{C} / \mathrm{FP}-(\mathrm{F} 11 \mathrm{~L} 12 \mathrm{G} 13)_{\mathrm{N}}$, (g) FP-(F11L12G13) /FP-(F8L9G10) $_{\mathrm{N}}$, and (h) FPK3-(A14A15G16) $\mathrm{C}$ /FPK3$(\mathrm{G} 5 \mathrm{~A} 6 \mathrm{~L} 7)_{\mathrm{N}}$. Samples in $(\mathrm{a}-\mathrm{d})$ primarily probed the presence of parallel strand arrangements and samples in $(\mathrm{e}-\mathrm{h})$ primarily probed the presence of antiparallel strand arrangements. The dotted lines are included for visual comparison of the spectral intensities. These measurements were taken under the same conditions as described in Figure 1 except that the dephasing period was $24.0 \mathrm{~ms}$ and the number of scans for each spectrum $\left(S_{0}\right.$ or $\left.S_{1}\right)$ was $\sim 100000$ for FP peptide samples and $\sim 200000$ for FPK3 peptide samples.

Table 2: REDOR Measurements of Carbonyl- and Amide-Labeled Membrane-Associated Fusion Peptides ${ }^{a}$

\begin{tabular}{|c|c|c|c|}
\hline & sample ${ }^{b}$ & $\Delta S / S_{0}^{c}$ & figure \\
\hline parallel arrangement probed & 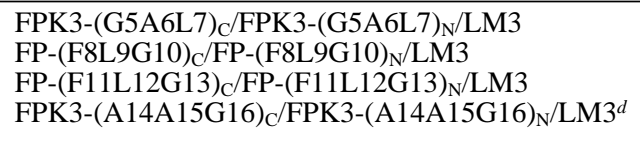 & $\begin{array}{r}0.13(0.01) \\
0.13(0.01) \\
0.11(0.01) \\
\left\{\begin{array}{l}0.01(0.03) \\
0.04(0.02)\end{array}\right.\end{array}$ & $\begin{array}{l}4 \mathrm{a} \\
4 \mathrm{~b} \\
4 \mathrm{c} \\
4 \mathrm{~d} \\
\mathrm{~ns}^{e}\end{array}$ \\
\hline antiparallel arrangement probed & $\begin{array}{l}\text { FPK3-(G5A6L7) })_{\mathrm{C}} / \mathrm{FPK} 3-(\mathrm{A} 14 \mathrm{~A} 15 \mathrm{G} 16)_{\mathrm{N}} / \mathrm{LM} 3^{d} \\
\text { FP-(F8L9G10) } / \text { FP-(F11L12G13) } / \mathrm{LM} 3 \\
\text { FP-(F11L12G13) })_{\mathrm{C}} / \mathrm{FP}-(\mathrm{F} 8 \mathrm{~L} 9 \mathrm{G} 10)_{\mathrm{N}} / \mathrm{LM} 3 \\
\text { FPK3-(A14A15G16)/FPK3-(G5A6L7) } / \mathrm{LM} 3\end{array}$ & $\begin{array}{l}\left\{\begin{array}{l}0.11(0.01) \\
0.12(0.02)\end{array}\right. \\
0.08(0.02) \\
0.09(0.02) \\
0.16(0.02)\end{array}$ & $\begin{array}{l}\mathrm{ns} \\
4 \mathrm{e} \\
4 \mathrm{f} \\
4 \mathrm{~g} \\
4 \mathrm{~h}\end{array}$ \\
\hline
\end{tabular}

${ }^{a}$ The dephasing time was $24.0 \mathrm{~ms} .{ }^{b}$ The overall peptide:lipid mole ratio was $\sim 0.04$, and the peptide:peptide mole ratio was $\sim 1 .{ }^{c}$ The uncertainty is enclosed in parentheses. ${ }^{d}$ Two samples were prepared and measured separately. ${ }^{e}$ Not shown in a figure.

of the oligomer. The apolar end of the oligomer may insert into the membrane so that, in this region, the strands must hydrogen bond to one another, while the polar end of the oligomer is likely outside the membrane where the strands would hydrogen bond to water. This model is supported by previous measurements of carbonyl line widths along the peptide backbone (45). In the N-terminal and central regions, the line widths are 2-3 ppm, which indicates a narrow distribution of secondary structures with a regular hydrogenbonding pattern, whereas in the C-terminal region, the line widths are $\sim 5 \mathrm{ppm}$, which indicates random coil structure and irregular hydrogen bonding.

Four samples (cf. Figure 4e,f) were also prepared to probe for antiparallel arrangement of peptide strands. The midpoint of the arrangement was chosen to be between Gly-10 and Phe-11, which is about the middle of the peptide. For example, the sample used for Figure $4 \mathrm{~h}$ contained peptide which was ${ }^{13} \mathrm{C}$ labeled at Ala-14, Ala-15, and Gly-16 and peptide which was ${ }^{15} \mathrm{~N}$ labeled at Gly-5, Ala-6, and Leu-7. For these four "antiparallel arrangement" samples, the $\Delta S /$ $S_{0}$ values were in the $0.08-0.16$ range and were significantly above the background level. Thus, in addition to the previously described parallel strand population, there also appears to be an antiparallel strand population whose interpeptide hydrogen bonding continues at least from Gly-5 to Gly-16. This result is schematically presented in Figure 5 b. For extended peptides in an oligomeric antiparallel strand arrangement, there would be both polar and apolar ends of 
(a)

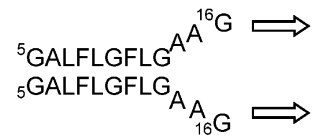

(b)

${ }^{5} \mathrm{GALFLGLGAA}^{16} \mathrm{G} \rightleftharpoons$ ${ }_{16}$ GAAGLFGLFLA ${ }_{5} \mathrm{G}$

FIGURE 5: Peptide oligomerization models for the (a) parallel strand arrangement and (b) antiparallel strand arrangement. The arrows indicate the peptide direction from the $\mathrm{N}$-terminus to $\mathrm{C}$-terminus while the numbers label the indices of individual residues. Interpeptide hydrogen bonding was detected along the whole length of the antiparallel arrangement and along the Gly-5 to Gly-13 length of the parallel arrangement. Interpeptide hydrogen bonding was considerably weaker in the Ala-14 to Gly-16 region of the parallel arrangement.

strands on each end of the oligomer, which is qualitatively different than what is expected for a parallel strand arrangement. Because of this mixed polarity, it is less clear whether an antiparallel oligomer would insert into the membrane.

Because most samples which probed for parallel and antiparallel strand arrangements had comparable $\Delta S / S_{0}$ values, it is likely that there are roughly equal populations of each arrangement. Such arrangements could exist for fully extended peptides in a $\beta$ sheet or $\beta$ barrel structure, or they could exist for peptides in a $\beta$ hairpin structure. There will be intrapeptide as well as interpeptide hydrogen bonding in the hairpin structure, and we are working to detect possible intrapeptide hydrogen bonding with a new set of ${ }^{13} \mathrm{C}-{ }^{15} \mathrm{~N}$ REDOR experiments. For the present interpeptide hydrogenbonding study, we also considered whether $\Delta S / S_{0}$ values predicted for a totally extended oligomeric $\beta$ strand model matched the experimental $\Delta S / S_{0}$ values. If the experimental values are significantly less than the predicted values, then there may be a population of hairpin peptides with intrapeptide hydrogen bonding.

In the extended peptide model, we considered that the total $S_{0}$ carbonyl signal had contributions from labeled ${ }^{13} \mathrm{C}$ in the peptide, natural abundance ${ }^{13} \mathrm{C}$ in the peptide, and natural abundance ${ }^{13} \mathrm{C}$ in the lipid. These contributions are denoted $S_{0}{ }^{\mathrm{C}}, S_{0}^{\mathrm{N}}$, and $S_{0}^{\mathrm{L}}$, respectively. There are corresponding contributions $S_{1}{ }^{\mathrm{C}}, S_{1}{ }^{\mathrm{N}}$, and $S_{1}{ }^{\mathrm{L}}$ to the total $S_{1}$ signal. In quantitating ${ }^{13} \mathrm{C}$, one ${ }^{13} \mathrm{C}$-labeled peptide, one ${ }^{15} \mathrm{~N}$-labeled peptide, and 50 lipid molecules are considered in the sample. The ${ }^{13} \mathrm{C}$ peptide has three labels, and $S_{0}{ }^{\mathrm{C}}$ is set to 3.0. The following calculations were made for the other $S_{0}$ signals:

$S_{0}{ }^{\mathrm{N}}=$ (number of unlabeled peptide carbonyl C) $\times$

(natural abundance ${ }^{13} \mathrm{C}$ ) $=49 \times 0.011=0.539$

$S_{0}{ }^{\mathrm{L}}=($ number of lipid) $\times$

(number of lipid carbonyl $\mathrm{C}$ per lipid molecule) $\times$

(signal per lipid ${ }^{13} \mathrm{C} /$ signal per peptide ${ }^{13} \mathrm{C}$ ) $\times$

(natural abundance ${ }^{13} \mathrm{C}$ ) $=50 \times 2 \times 0.11 \times 0.011=$

For the $S_{0}{ }^{\mathrm{N}}$ calculation, we considered the FPK3 peptide with 26 residues. As described in the REDOR Control Experiments section, $S_{1}{ }^{\mathrm{L}} \approx S_{0}^{\mathrm{L}}$. Considering the spectrum displayed in Figure $3 c$, we approximate that $S_{1}{ }^{\mathrm{N}} \approx 0.8 \times S_{0}{ }^{\mathrm{N}}=0.431$. Considering the spectrum displayed in Figure $3 \mathrm{a}$ and the correction factor described in the REDOR Control Experiments section, we expect that the $\Delta S / S_{0}$ for a single hydrogen-bonded ${ }^{13} \mathrm{C}-{ }^{15} \mathrm{~N}$ pair is in the range of $0.45-0.50$. For the samples used in this study, the labeled ${ }^{13} \mathrm{C}$ could be dipole-coupled to a ${ }^{15} \mathrm{~N}$ hydrogen bond partner on the neighboring strand and also dipole-coupled to the more distant labeled ${ }^{15} \mathrm{~N}$ on this strand. Simulations of the REDOR experiment were performed with this four-spin $\beta$ sheet geometry (one ${ }^{13} \mathrm{C}+$ three ${ }^{15} \mathrm{~N}$ ) and showed that the two more distant ${ }^{15} \mathrm{~N}$ increased $\Delta S / S_{0}$ by $\sim 10 \%$ over that of a single ${ }^{13} \mathrm{C}-{ }^{15} \mathrm{~N}$ pair. Combining the experimental and simulation results, we approximate that $S_{1} \mathrm{C} \approx 0.50 S_{0} \mathrm{C}$ for the case where all three labeled ${ }^{13} \mathrm{C}$ on one strand are hydrogen bonded with ${ }^{15} \mathrm{~N}$ on adjacent strands. Because the experimental samples contain a 1:1 mixture of ${ }^{13} \mathrm{C}$ - and ${ }^{15} \mathrm{~N}$ labeled peptide, there is only $50 \%$ probability that a ${ }^{13} \mathrm{C}$ labeled strand will be adjacent to a ${ }^{15} \mathrm{~N}$-labeled strand. Therefore, a corrected $S_{1}{ }^{\mathrm{C}} \approx 0.75 S_{0}{ }^{\mathrm{C}}=2.25$ was used in the calculations.

Using all of these results, the total $\Delta S / S_{0}$ for the extended strand model was calculated:

$$
\begin{aligned}
\Delta S / S_{0}=1-\left(S_{1} / S_{0}\right)= & 1-(2.25+0.431+0.121) / \\
& (3.0+0.539+0.121)=0.23
\end{aligned}
$$

As described in the REDOR Control Experiments section, $\left(\Delta S / S_{0}\right)_{\text {background }} \sim 0.03$, so the labeled ${ }^{13} \mathrm{C}-{ }^{15} \mathrm{~N}$ hydrogen bond contribution to dephasing, $\left(\Delta S / S_{0}\right)_{\text {model }}$, is $\sim 0.20$. Comparison with experimental data was made using results from the FPK3-(G5A6L7) $/$ FPK3-(G5A6L7) $)_{N} / L M 3$ and the FPK3-(G5A6L7) $\mathrm{C} / \mathrm{FPK} 3-(\mathrm{A} 14 \mathrm{~A} 15 \mathrm{~A} 16)_{\mathrm{N}} / \mathrm{LM} 3$ samples as

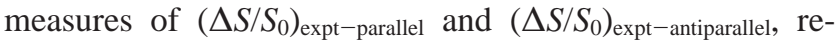
spectively. After subtracting $\left(\Delta S / S_{0}\right)_{\text {background }}$ from each of the experimental $\Delta S / S_{0}$, we obtain values of $\left(\Delta S / S_{0}\right)_{\text {expt-parallel }}$ $\approx 0.10$ and $\left(\Delta S / S_{0}\right)_{\text {expt-antiparallel }} \approx 0.08$. The total hydrogenbonding component of $\Delta S / S_{0}$ for the FPK3-(G5A6L7) peptide, $\left(\Delta S / S_{0}\right)_{\text {expt }}$, is $\sim 0.18$, which is comparable to $(\Delta S /$ $\left.S_{0}\right)_{\text {model }}$. This result suggests that the extended oligomeric structures account for much of the membrane-associated peptide population. The $10-15 \%$ difference between $(\Delta S /$ $\left.S_{0}\right)_{\text {model }}$ and $\left(\Delta S / S_{0}\right)_{\text {expt }}$ could be due to uncertainties in the experimental data and model, different alignments of peptide strands than the fully in-register arrangements used for the model, and/or a population of $\beta$ turn peptides with intrapeptide hydrogen bonding. Intrapeptide hydrogen bonding was not probed in the experiments of this study.

\section{DISCUSSION}

The structural plasticity of membrane-associated viral fusion peptides has been observed by several groups using a variety of experimental probes, and it is known that they can exist in well-structured helical or nonhelical forms (15, 103). Other investigators have developed structural models for the helical form of the peptides based principally on solution NMR, ESR, and infrared data $(38,44,52)$. In the present study, we applied solid-state NMR internuclear distance measurements to develop a structural model for the nonhelical form of the membrane-associated HIV-1 fusion peptide. This work was based on previous solid-state NMR chemical shift and 2D exchange measurements, which showed that the peptide is predominantly nonhelical when associated with membranes whose lipid headgroup and cholesterol composition is close to that found in host cells of the virus (45). One of the possible nonhelical structures 
is oligomeric $\beta$ strands held together by interpeptide hydrogen bonding, and we did experiments to detect this type of structure. In membrane-associated fusion peptide samples containing a 1:1 mixture of $\left[{ }^{13} \mathrm{C}\right]$ carbonyl-labeled and $\left[{ }^{15} \mathrm{~N}\right]-$ amide-labeled peptide, detection of ${ }^{13} \mathrm{C}-{ }^{15} \mathrm{~N}$ proximity by solid-state NMR REDOR measurements strongly supports this structural model. Moreover, the semiquantitative agreement between the $\Delta S / S_{0}$ values predicted by the model and the experimental $\Delta S / S_{0}$ values suggests that the oligomeric $\beta$ strand structure represents a substantial population of the membrane-associated peptide. Solid-state NMR experiments are currently underway to test whether all of the peptide is fully extended or whether there is also a population of peptide with hairpin structure.

A second important result is that the data were consistent with roughly equal populations of peptide in parallel or antiparallel strand arrangements. Interstrand hydrogen bonding was observed from Gly-5 through Gly-16 in the antiparallel arrangement but only from Gly-5 through Gly-13 in the parallel arrangement. C-terminal fraying in the parallel arrangement is consistent with previous solid-state NMR line width measurements and with a reasonable biophysical model in which the apolar $\mathrm{N}$-terminal and central regions of the oligomer insert into the membrane while the polar C-terminal region is outside the membrane (45). Experiments by other groups also suggest that the $\mathrm{C}$-terminal region is not membrane-inserted, although some of these measurements suggest that this region is helical, rather than the random coil structure indicated by our previously published experiments (22). These different structures may be a result of the different lengths of the C-terminal regions used in the different studies.

It is also useful to consider our results in the context of the expected fusion peptide topology in the gp41 protein. Structures of the gp41 soluble ectodomain begin around residue 30 and are trimeric with the three $\mathrm{N}$-termini in close proximity at the end of an in-register helical coiled-coil. These structures end several residues C-terminal of the fusion peptide, and it has been hypothesized that during viral/target cell fusion, at least three fusion peptides insert into the target cell membrane with their C-termini in close proximity (29$32,34)$. In the HIV-1 fusion peptide model system, the biological topology has been mimicked with C-terminal cross-linking, and it has been observed that, in many cases, the cross-linked peptides induce both a greater final extent and a more rapid rate of fusion than their non-cross-linked analogues (49). Similar fusogenic enhancements have been observed for influenza protein domains for which the fusion peptide is thought to assume the biologically relevant oligomeric topology $(21,38,51,104-107)$. In these contexts, it is appealing that a fusion peptide population was indeed observed in the present study with an approximately inregister parallel strand arrangement. This arrangement seems like a reasonable continuation of the known ectodomain oligomeric structure, and this arrangement also has a defined apolar region of the fusion peptide oligomer which could insert into the membrane and catalyze fusion. For the noncross-linked peptides used for the present study, a population of peptide with antiparallel strand arrangement was also observed. In the antiparallel arrangement, it is not as clear how the oligomer might insert into the membrane and catalyze fusion. Thus, the fusogenic enhancement of the
HIV-1 cross-linked peptides may be in part due to their preference for a parallel strand arrangement. One approach to testing this model would be to cross-link ${ }^{13} \mathrm{C}$ - and ${ }^{15} \mathrm{~N}$ labeled peptides and perform interstrand REDOR measurements similar to those described in this paper. Detection of larger $\Delta S / S_{0}$ for parallel strand labeling schemes relative to antiparallel schemes would provide experimental evidence for the model.

Formation of parallel and antiparallel strand arrangements for the membrane-associated HIV-1 fusion peptide appears to be qualitatively different from what has been found for peptides in solid amyloid fibrils. In amyloid, a single peptide sequence appears to form either a parallel or an antiparallel strand arrangement $(65,108-110)$.

The present study also provides some insight into oligomer formation. Analytical ultracentrifugation data strongly suggest that the 26-residue FPK3 construct is predominantly monomeric in the buffer solution, so formation of membraneassociated $\beta$ strand oligomers can be a direct result of peptide/membrane interaction. In addition, the analytical ultracentrifugation data suggest that the 23-residue FP construct forms a mixture of oligomeric states in the buffer solution. In the initial step of FP solid-state NMR sample preparation, separate solutions of ${ }^{13} \mathrm{C}$ - and ${ }^{15} \mathrm{~N}$-labeled peptide were made and contained either ${ }^{13} \mathrm{C}$ or ${ }^{15} \mathrm{~N}$ oligomers. After $\mathrm{FP} /$ membrane association, the solid-state NMR REDOR data showed significant $\Delta S / S_{0}$ values (comparable to those of FPK3 samples), which means that the membrane-associated FP oligomers were a molecular mixture of ${ }^{13} \mathrm{C}$ - and ${ }^{15} \mathrm{~N}$ labeled peptides. This transformation from separated to mixed oligomers could have been a result of exchange in aqueous solution. However, the ${ }^{13} \mathrm{C}$ and ${ }^{15} \mathrm{~N}$ peptide solutions were mixed only briefly prior to addition of liposomes, and we believe that it is more likely that the FP oligomers disassemble and reassemble upon interaction with the membrane. This disassembly/reassembly model is consistent with the experimental observation that an influenza fusion peptide which is oligomeric in aqueous solution can be converted to a helical structure upon membrane binding $(48,88)$. It is also consistent with ideas and experiments from other groups $(20,42)$; in particular, the fusogenically disruptive Val-2 to Glu-2 point mutation in the HIV-1 fusion peptide was correlated with formation of peptide dimers rather than the larger oligomers found for the wild-type peptide (16). It was therefore hypothesized that the mutant peptide prevented the proper membrane-mediated assembly of peptides required for fusion activity.

There are several remaining questions about the structures of membrane-associated oligomeric $\beta$ strand HIV-1 fusion peptides including (1) the relative populations of hairpin and extended structures, (2) the effect of the biologically relevant oligomeric topology on the relative populations of parallel and antiparallel strand arrangements, (3) the overall oligomer size and the number of peptides with a particular strand arrangement, (4) the precise residue register(s) between neighboring strands in a particular arrangement, (5) the insertion of the oligomer into the membrane, and (6) and the overall oligomer structure which satisfies hydrogen bonding for most of the carbonyl oxygens and amide protons. Question 5 has been previously investigated with fluorescence and ESR measurements, but the data analyses may have been complicated by the presence of parallel and 
antiparallel oligomers which may have different insertion depths $(16,35,111)$. Larger biological questions include the relative fusogenicities of the helical and nonhelical forms of the peptide and the possible role of transient structures in fusion catalysis. At least for the influenza fusion peptide, it appears that both helical and nonhelical forms are fusogenic and that there is not a single transient fusogenic structure. The relative populations of helical and nonhelical peptide structures are significantly affected by the lipid and cholesterol composition of the target membrane (88). A combination of experiments, simulation, and modeling will likely be necessary to understand the specific peptide/lipid and peptide/ cholesterol interactions which determine the overall peptide structure $(52,55,112)$.

In summary, solid-state NMR has been applied to detect oligomeric $\beta$ strand structure in the membrane-associated HIV-1 fusion peptide. A roughly equal mixture of parallel and antiparallel strand arrangements was observed with fraying of the strands toward the $\mathrm{C}$-terminus in the parallel arrangement. These studies provide a basis to develop a more refined model of the peptide structure and to understand how it may catalyze membrane fusion.

\section{ACKNOWLEDGMENT}

We acknowledge Drs. Mary Prorok and Mark Lemmon for assistance with acquisition and analysis of analytical ultracentrifugation data, Dr. Terry Gullion for useful discussions and for assistance with the setup of the REDOR experiments, Dr. Robert Tycko for useful discussions and for providing REDOR pulse programs, Drs. Honggao Yan and David DeWitt for use of their fluorometer and ultracentrifuge, respectively, The Michigan State University Mass Spectrometry and Macromolecular Structure Facilities for assistance with mass spectrometric analysis and amino acid analysis, respectively, and Brian Dodds and Andrew Goetz for assistance with peptide purification.

\section{REFERENCES}

1. Hernandez, L. D., Hoffman, L. R., Wolfsberg, T. G., and White, J. M. (1996) Virus-cell and cell-cell fusion, Annu. Rev. Cell Dev. Biol. 12, 627-661.

2. Dimitrov, D. S. (2000) Cell biology of virus entry, Cell 101, 697702.

3. Eckert, D. M., and Kim, P. S. (2001) Mechanisms of viral membrane fusion and its inhibition, Annu. Rev. Biochem. 70, 777810 .

4. Blumenthal, R., Clague, M. J., Durell, S. R., and Epand, R. M. (2003) Membrane fusion, Chem. Rev. 103, 53-69.

5. Freed, E. O., Myers, D. J., and Risser, R. (1990) Characterization of the fusion domain of the human immunodeficiency virus type 1 envelope glycoprotein gp41, Proc. Natl. Acad. Sci. U.S.A. 87, 4650-4654.

6. Rafalski, M., Lear, J. D., and DeGrado, W. F. (1990) Phospholipid interactions of synthetic peptides representing the $\mathrm{N}$-terminus of HIV gp41, Biochemistry 29, 7917-7922.

7. Slepushkin, V. A., Melikyan, G. B., Sidorova, M. S., Chumakov, V. M., Andreev, S. M., Manulyan, R. A., and Karamov, E. V. (1990) Interaction of human immunodeficiency virus (HIV-1) fusion peptides with artificial lipid membranes, Biochem. Biophys. Res. Commun. 172, 952-957.

8. Freed, E. O., Delwart, E. L., Buchschacher, G. L., Jr., and Panganiban, A. T. (1992) A mutation in the human immunodeficiency virus type 1 transmembrane glycoprotein gp41 dominantly interferes with fusion and infectivity, Proc. Natl. Acad. Sci. U.S.A. $89,70-74$

9. Martin, I., Defrise-Quertain, F., Decroly, E., Vandenbranden, M., Brasseur, R., and Ruysschaert, J. M. (1993) Orientation and structure of the $\mathrm{NH}_{2}$-terminal HIV-1 gp41 peptide in fused and aggregated liposomes, Biochim. Biophys. Acta 1145, 124-133.

10. Nieva, J. L., Nir, S., Muga, A., Goni, F. M., and Wilschut, J. (1994) Interaction of the HIV-1 fusion peptide with phospholipid vesicles: different structural requirements for fusion and leakage, Biochemistry 33, 3201-3209.

11. Mobley, P. W., Lee, H. F., Curtain, C. C., Kirkpatrick, A., Waring, A. J., and Gordon, L. M. (1995) The amino-terminal peptide of HIV-1 glycoprotein 41 fuses human erythrocytes, Biochim. Biophys. Acta 1271, 304-314.

12. Schaal, H., Klein, M., Gehrmann, P., Adams, O., and Scheid, A (1995) Requirement of N-terminal amino acid residues of gp41 for human immunodeficiency virus type 1-mediated cell fusion, J. Virol. 69, 3308-3314.

13. Delahunty, M. D., Rhee, I., Freed, E. O., and Bonifacino, J. S. (1996) Mutational analysis of the fusion peptide of the human immunodeficiency virus type 1: identification of critical glycine residues, Virology 218, 94-102.

14. Martin, I., Schaal, H., Scheid, A., and Ruysschaert, J. M. (1996) Lipid membrane fusion induced by the human immunodeficiency virus type 1 gp41 N-terminal extremity is determined by its orientation in the lipid bilayer, J. Virol. 70, 298-304.

15. Durell, S. R., Martin, I., Ruysschaert, J. M., Shai, Y., and Blumenthal, R. (1997) What studies of fusion peptides tell us about viral envelope glycoprotein-mediated membrane fusion (review), Mol. Membr. Biol. 14, 97-112.

16. Kliger, Y., Aharoni, A., Rapaport, D., Jones, P., Blumenthal, R., and Shai, Y. (1997) Fusion peptides derived from the HIV type 1 glycoprotein 41 associate within phospholipid membranes and inhibit cell-cell Fusion. Structure-function study, J. Biol. Chem. 272, 13496-13505.

17. Pereira, F. B., Goni, F. M., Muga, A., and Nieva, J. L. (1997) Permeabilization and fusion of uncharged lipid vesicles induced by the HIV-1 fusion peptide adopting an extended conformation: dose and sequence effects, Biophys. J. 73, 1977-1986.

18. Nieva, J. L., Nir, S., and Wilschut, J. (1998) Destabilization and fusion of zwitterionic large unilamellar lipid vesicles induced by a $\beta$-type structure of the HIV-1 fusion peptide, J. Liposome Res. $8,165-182$.

19. Pecheur, E., Sainte-Marie, J., Bienvenue, A., and Hoekstra, D. (1999) Peptides and membrane fusion: towards an understanding of the molecular mechanism of protein-induced fusion, J. Membr. Biol. 167, 1-17.

20. Pritsker, M., Rucker, J., Hoffman, T. L., Doms, R. W., and Shai, Y. (1999) Effect of nonpolar substitutions of the conserved Phe11 in the fusion peptide of HIV-1 gp41 on its function, structure, and organization in membranes, Biochemistry 38, 11359-11371.

21. Epand, R. F., Macosko, J. C., Russell, C. J., Shin, Y. K., and Epand, R. M. (1999) The ectodomain of HA2 of influenza virus promotes rapid $\mathrm{pH}$ dependent membrane fusion, J. Mol. Biol. 286, 489-503.

22. Peisajovich, S. G., Epand, R. F., Pritsker, M., Shai, Y., and Epand, R. M. (2000) The polar region consecutive to the HIV fusion peptide participates in membrane fusion, Biochemistry 39, 18261833.

23. Peisajovich, S. G., Samuel, O., and Shai, Y. (2000) Paramyxovirus F1 protein has two fusion peptides: implications for the mechanism of membrane fusion, J. Mol. Biol. 296, 1353-1365.

24. Suarez, T., Gallaher, W. R., Agirre, A., Goni, F. M., and Nieva, J. L. (2000) Membrane interface-interacting sequences within the ectodomain of the human immunodeficiency virus type 1 envelope glycoprotein: putative role during viral fusion, J. Virol. 74, 80388047.

25. Sackett, K., and Shai, Y. (2002) The HIV-1 gp41 N-Terminal Heptad Repeat Plays an Essential Role in Membrane Fusion, Biochemistry 41, 4678-4685.

26. Peisajovich, S. G., Blank, L., Epand, R. F., Epand, R. M., and Shai, Y. (2003) On the interaction between gp41 and membranes: The immunodominant loop stabilizes gp41 helical hairpin conformation, J. Mol. Biol. 326, 1489-1501.

27. Wilson, I. A., Skehel, J. J., and Wiley, D. C. (1981) Structure of the haemagglutinin membrane glycoprotein of influenza virus at $3 \AA$ resolution, Nature 289, 366-373.

28. Bullough, P. A., Hughson, F. M., Skehel, J. J., and Wiley, D. C. (1994) Structure of influenza haemagglutinin at the $\mathrm{pH}$ of membrane fusion, Nature 371, 37-43.

29. Chan, D. C., Fass, D., Berger, J. M., and Kim, P. S. (1997) Core structure of gp41 from the HIV envelope glycoprotein, Cell 89, 263-273 
30. Tan, K., Liu, J., Wang, J., Shen, S., and Lu, M. (1997) Atomic structure of a thermostable subdomain of HIV-1 gp41, Proc. Natl. Acad. Sci. U.S.A. 94, 12303-12308.

31. Weissenhorn, W., Dessen, A., Harrison, S. C., Skehel, J. J., and Wiley, D. C. (1997) Atomic structure of the ectodomain from HIV-1 gp41, Nature 387, 426-430.

32. Caffrey, M., Cai, M., Kaufman, J., Stahl, S. J., Wingfield, P. T., Covell, D. G., Gronenborn, A. M., and Clore, G. M. (1998) Threedimensional solution structure of the $44 \mathrm{kDa}$ ectodomain of SIV gp41, EMBO J. 17, 4572-4584.

33. Chen, J., Skehel, J. J., and Wiley, D. C. (1999) N- and C-terminal residues combine in the fusion-pH influenza hemagglutinin $\mathrm{HA}_{2}$ subunit to form an $\mathrm{N}$ cap that terminates the triple-stranded coiled coil, Proc. Natl. Acad. Sci. U.S.A. 96, 8967-8972.

34. Yang, Z. N., Mueser, T. C., Kaufman, J., Stahl, S. J., Wingfield, P. T., and Hyde, C. C. (1999) The crystal structure of the SIV gp41 ectodomain at $1.47 \AA$ resolution, J. Struct. Biol. 126, 131144.

35. Gordon, L. M., Curtain, C. C., Zhong, Y. C., Kirkpatrick, A., Mobley, P. W., and Waring, A. J. (1992) The amino-terminal peptide of HIV-1 glycoprotein 41 interacts with human erythrocyte membranes: peptide conformation, orientation and aggregation, Biochim. Biophys. Acta 1139, 257-274.

36. Pereira, F. B., Goni, F. M., and Nieva, J. L. (1995) Liposome destabilization induced by the HIV-1 fusion peptide effect of a single amino acid substitution, FEBS Lett. 362, 243-246.

37. Chang, D. K., Cheng, S. F., and Chien, W. J. (1997) The aminoterminal fusion domain peptide of human immunodeficiency virus type 1 gp41 inserts into the sodium dodecyl sulfate micelle primarily as a helix with a conserved glycine at the micelle-water interface, J. Virol. 71, 6593-6602.

38. Macosko, J. C., Kim, C. H., and Shin, Y. K. (1997) The membrane topology of the fusion peptide region of influenza hemagglutinin determined by spin-labeling EPR, J. Mol. Biol. 267, 1139-1148.

39. Mobley, P. W., Waring, A. J., Sherman, M. A., and Gordon, L. M. (1999) Membrane interactions of the synthetic N-terminal peptide of HIV-1 gp41 and its structural analogues, Biochim. Biophys. Acta 1418, 1-18.

40. Curtain, C., Separovic, F., Nielsen, K., Craik, D., Zhong, Y., and Kirkpatrick, A. (1999) The interactions of the N-terminal fusogenic peptide of HIV-1 gp41 with neutral phospholipids, Eur. Biophys. J. 28, 427-436.

41. Han, X., and Tamm, L. K. (2000) A host-guest system to study structure-function relationships of membrane fusion peptides, Proc. Natl. Acad. Sci. U.S.A. 97, 13097-13102.

42. Han, X., and Tamm, L. K. (2000) pH-dependent self-association of influenza hemagglutinin fusion peptides in lipid bilayers, $J$. Mol. Biol. 304, 953-965.

43. Dubovskii, P. V., Li, H., Takahashi, S., Arseniev, A. S., and Akasaka, K. (2000) Structure of an analog of fusion peptide from hemagglutinin, Protein Sci. 9, 786-798.

44. Han, X., Bushweller, J. H., Cafiso, D. S., and Tamm, L. K. (2001) Membrane structure and fusion-triggering conformational change of the fusion domain from influenza hemagglutinin, Nat. Struct. Biol. 8, 715-720.

45. Yang, J., Gabrys, C. M., and Weliky, D. P. (2001) Solid-state nuclear magnetic resonance evidence for an extended $\beta$ strand conformation of the membrane-bound HIV-1 fusion peptide, Biochemistry 40, 8126-8137.

46. Hsu, C. H., Wu, S. H., Chang, D. K., and Chen, C. P. (2002) Structural characterizations of fusion peptide analogs of influenza virus hemagglutinin-Implication of the necessity of a helix-hingehelix motif in fusion activity, J. Biol. Chem. 277, 22725-22733.

47. Gordon, L. M., Mobley, P. W., Pilpa, R., Sherman, M. A., and Waring, A. J. (2002) Conformational mapping of the N-terminal peptide of HIV-1 gp41 in membrane environments using C-13enhanced Fourier transform infrared spectroscopy, Biochim. Biophys. Acta 1559, 96-120.

48. Yang, J., Parkanzky, P. D., Bodner, M. L., Duskin, C. G., and Weliky, D. P. (2002) Application of REDOR subtraction for filtered MAS observation of labeled backbone carbons of membrane-bound fusion peptides, J. Magn. Reson. 159, 101-110.

49. Yang, R., Yang, J., and Weliky, D. P. (2003) Synthesis, enhanced fusogenicity, and solid-state NMR measurements of cross-linked HIV-1 fusion peptides, Biochemistry 42, 3527-3535.

50. Bodner, M. L., Gabrys, C. M., Parkanzky, P. D., Yang, J., Duskin, C. A., and Weliky, D. P. (2003) Temperature dependence and resonance assignment of ${ }^{13} \mathrm{C}$ NMR spectra of selectively and uniformly labeled fusion peptides associated with membranes, Magn. Reson. Chem. (in press).

51. LeDuc, D. L., Shin, Y. K., Epand, R. F., and Epand, R. M. (2000) Factors determining vesicular lipid mixing induced by shortened constructs of influenza hemagglutinin, Biochemistry 39, 27332739.

52. Epand, R. M., Epand, R. F., Martin, I., and Ruysschaert, J. M. (2001) Membrane interactions of mutated forms of the influenza fusion peptide, Biochemistry 40, 8800-8807.

53. Kamath, S., and Wong, T. C. (2002) Membrane structure of the human immunodeficiency virus gp41 fusion domain by molecular dynamics simulation, Biophys. J. 83, 135-143.

54. Maddox, M. W., and Longo, M. L. (2002) Conformational partitioning of the fusion peptide of HIV-1 gp41 and its structural analogues in bilayer membranes, Biophys. J. 83, 3088-3096.

55. Tamm, L. K., Han, X., Li, Y. L., and Lai, A. L. (2002) Structure and function of membrane fusion peptides, Biopolymers 66, 249260.

56. Wong, T. C. (2003) Membrane structure of the human immunodeficiency virus gp41 fusion peptide by molecular dynamics simulation II. The glycine mutants, Biochim. Biophys. Acta 1609, $45-54$.

57. Taylor, S. E., Desbat, B., Blaudez, D., Jacobi, S., Chi, L. F., Fuchs, H., and Schwarz, G. (2000) Structure of a fusion peptide analogue at the air-water interface, determined from surface activity, infrared spectroscopy and scanning force microscopy, Biophys. Chem. 87, 63-72.

58. Haque, M. E., Koppaka, V., Axelsen, P. H., and Lentz, B. R. (2002) Relation between bilayer properties and structures of HA and HIV fusion peptide-membrane complexes, Biophys. J. 82, $540 \mathrm{a}$.

59. Munoz-Barroso, I., Durell, S., Sakaguchi, K., Appella, E., and Blumenthal, R. (1998) Dilation of the human immunodeficiency virus-1 envelope glycoprotein fusion pore revealed by the inhibitory action of a synthetic peptide from gp41, J. Cell Biol. 140, $315-323$.

60. Bentz, J. (2000) Minimal aggregate size and minimal fusion unit for the first fusion pore of influenza hemagglutinin-mediated membrane fusion, Biophys. J. 78, 227-245.

61. Bentz, J. (2000) Membrane fusion mediated by coiled coils: a hypothesis, Biophys. J. 78, 886-900.

62. Gullion, T., and Schaefer, J. (1989) Rotational-echo doubleresonance NMR, J. Magn. Reson. 81, 196-200.

63. Anderson, R. C., Gullion, T., Joers, J. M., Shapiro, M., Villhauer, E. B., and Weber, H. P. (1995) Conformation of $\left[1{ }^{13} \mathrm{C},{ }^{15} \mathrm{~N}\right]$ acetylL-carnitine. Rotational-echo, double-resonance nuclear magnetic resonance spectroscopy, J. Am. Chem. Soc. 117, 10546-10550.

64. Gullion, T. (1998) Introduction to rotational-echo, doubleresonance NMR, Concepts Magn. Reson. 10, 277-289.

65. Balbach, J. J., Ishii, Y., Antzutkin, O. N., Leapman, R. D., Rizzo, N. W., Dyda, F., Reed, J., and Tycko, R. (2000) Amyloid fibril formation by $\mathrm{A} \beta$ 16-22, a seven-residue fragment of the Alzheimer's $\beta$-amyloid peptide, and structural characterization by solid-state NMR, Biochemistry 39, 13748-13759.

66. Kimura, S., Naito, A., Saito, H., Ogawa, K., and Shoji, A. (2001) Characterization of $\alpha$-helix structures in polypeptides, revealed by ${ }^{13} \mathrm{C}=\mathrm{O} \cdots \mathrm{H}-{ }^{15} \mathrm{~N}$ hydrogen bond lengths determined by ${ }^{13} \mathrm{C}$ REDOR NMR, J. Mol. Struct. 562, 197-203.

67. Murphy, O. J., III, Kovacs, F. A., Sicard, E. L., and Thompson, L. K. (2001) Site-directed solid-state NMR measurement of a ligand-induced conformational change in the serine bacterial chemoreceptor, Biochemistry 40, 1358-1366.

68. Jaroniec, C. P., Lansing, J. C., Tounge, B. A., Belenky, M., Herzfeld, J., and Griffin, R. G. (2001) Measurement of dipolar couplings in a uniformly ${ }^{13} \mathrm{C},{ }^{15} \mathrm{~N}$ labeled membrane protein: Distances between the Schiff base and aspartic acids in the active site of bacteriorhodopsin, J. Am. Chem. Soc. 123, 12929-12930.

69. Smith, S. O., Eilers, M., Song, D., Crocker, E., Ying, W. W., Groesbeek, M., Metz, G., Ziliox, M., and Aimoto, S. (2002) Implications of threonine hydrogen bonding in the glycophorin A transmembrane helix dimer, Biophys. J. 82, 2476-2486.

70. Thompson, L. K. (2002) Solid-state NMR studies of the structure and mechanisms of proteins, Curr. Opin. Struct. Biol. 12, 661669.

71. Nishimura, K., Kim, S. G., Zhang, L., and Cross, T. A. (2002) The closed state of a $\mathrm{H}^{+}$channel helical bundle combining precise orientational and distance restraints from solid-state NMR, Biochemistry 41, 13170-13177. 
72. Cegelski, L., Kim, S. J., Hing, A. W., Studelska, D. R., O’Connor, R. D., Mehta, A. K., and Schaefer, J. (2002) Rotational-echo double resonance characterization of the effects of vancomycin on cell wall synthesis in Staphylococcus aureus, Biochemistry 41, 13053-13058.

73. Long, H. W., and Tycko, R. (1998) Biopolymer conformational distributions from solid-state NMR: $\alpha$-helix and $3_{10}$-helix contents of a helical peptide, J. Am. Chem. Soc. 120, 7039-7048.

74. Chang, C. D., Waki, M., Ahmad, M., Meienhofer, J., Lundell, E. O., and Haug, J. D. (1980) Preparation and properties of N- $\alpha-9$ fluorenylmethyloxycarbonylamino acids bearing tert-butyl sidechain protection, Int. J. Pept. Protein Res. 15, 59-66.

75. Lapatsanis, L., Milias, G., Froussios, K., and Kolovos, M. (1983) Synthesis of N-2,2,2-(trichloroethoxycarbonyl)-L-amino acids and $\mathrm{N}$-(9-fluorenylmethoxycarbonyl)-L-amino acids involving succinimidoxy anion as a leaving group in amino acid protection, Synthesis 8, 671-673.

76. Aloia, R. C., Tian, H., and Jensen, F. C. (1993) Lipid composition and fluidity of the human immunodeficiency virus envelope and host cell plasma membranes, Proc. Natl. Acad. Sci. U.S.A. 90, 5181-5185.

77. Hope, M. J., Bally, M. B., Webb, G., and Cullis, P. R. (1985) Production of large unilamellar vesicles by a rapid extrusion procedure-characterization of size distribution, trapped volume and ability to maintain a membrane-potential, Biochim. Biophys. Acta 812, 55-65.

78. Struck, D. K., Hoekstra, D., and Pagano, R. E. (1981) Use of resonance energy transfer to monitor membrane fusion, Biochemistry 20, 4093-4099.

79. Bennett, A. E., Rienstra, C. M., Auger, M., Lakshmi, K. V., and Griffin, R. G. (1995) Heteronuclear decoupling in rotating solids, J. Chem. Phys. 103, 6951-6958.

80. Gullion, T., Baker, D. B., and Conradi, M. S. (1990) New, compensated Carr-Purcell sequences, J. Magn. Reson. 89, 479484.

81. Gullion, T., and Schaefer, J. (1991) Elimination of resonance offset effects in rotational-echo, double-resonance NMR, J. Magn. Reson. 92, 439-442.

82. McDowell, L. M., Holl, S. M., Qian, S. J., Li, E., and Schaefer, J. (1993) Inter-tryptophan distances in rat cellular retinol-binding protein II by solid-state NMR, Biochemistry 32, 4560-4563.

83. Bevington, P. R., and Robinson, D. K. (1992) Data Reduction and Error Analysis for the Physical Sciences, McGraw-Hill, Boston.

84. Bak, M., Rasmussen, J. T., and Nielsen, N. C. (2000) SIMPSON: A general simulation program for solid-state NMR spectroscopy, J. Magn. Reson. 147, 296-330.

85. Oas, T. G., Hartzell, C. J., McMahon, T. J., Drobny, G. P., and Dahlquist, F. W. (1987) The carbonyl ${ }^{13} \mathrm{C}$ chemical-shift tensors of 5 peptides determined from ${ }^{15} \mathrm{~N}$ dipole-coupled chemical-shift powder patterns, J. Am. Chem. Soc. 109, 5956-5962.

86. Balbach, J. J., Yang, J., Weliky, D. P., Steinbach, P. J., Tugarinov, V., Anglister, J., and Tycko, R. (2000) Probing hydrogen bonds in the antibody-bound HIV-1 gp120 V3 loop by solid-state NMR REDOR measurements, J. Biomol. NMR 16, 313-327.

87. Derrick, J. P., and Wigley, D. B. (1994) The third IgG-binding domain from streptococcal protein G. An analysis by X-ray crystallography of the structure alone and in a complex with Fab, J. Mol. Biol. 243, 906-918.

88. P. D. Parkanzky and, D. P. Weliky, unpublished experiments.

89. Kricheldorf, H. R., and Muller, D. (1983) Secondary structure of peptides. $3 .{ }^{13} \mathrm{C}$ cross polarization magic angle spinning spectroscopic characterization of solid polypeptides, Macromolecules 16, 615-623.

90. Saito, H. (1986) Conformation-dependent ${ }^{13} \mathrm{C}$ chemical-shifts-a new means of conformational characterization as obtained by highresolution solid-state ${ }^{13} \mathrm{C}$ NMR, Magn. Reson. Chem. 24, 835852.

91. Yang, J., Parkanzky, P. D., Khunte, B. A., Canlas, C. G., Yang, R., Gabrys, C. M., and Weliky, D. P. (2001) Solid-state NMR measurements of conformation and conformational distributions in the membrane-bound HIV-1 fusion peptide, J. Mol. Graphics Modell. 19, 129-135.

92. Morcombe, C. R., and Zilm, K. W. (2003) Chemical shift referencing in MAS solid-state NMR, J. Magn. Reson. 162, 479486 .

93. Zhang, H. Y., Neal, S., and Wishart, D. S. (2003) RefDB: A database of uniformly referenced protein chemical shifts, $J$. Biomol. NMR 25, 173-195.
94. Ishii, Y., Ashida, J., and Terao, T. (1995) ${ }^{13} \mathrm{C}-{ }^{1} \mathrm{H}$ Dipolar recoupling dynamics in ${ }^{13} \mathrm{C}$ multiple-pulse solid-state NMR, Chem. Phys. Lett. 246, 439-445.

95. Sun, B. Q., Costa, P. R., and Griffin, R. G. (1995) Heteronuclear polarization transfer by radiofrequency-driven dipolar recoupling under magic-angle-spinning, J. Magn. Reson. A 112, 191-198.

96. Mitchell, D. J., and Evans, J. N. S. (1998) Improved heteronuclear decoupling in REDOR with the use of TPPM, Chem. Phys. Lett. 292, 656-660.

97. Mehta, A. K., Hirsh, D. J., Oyler, N., Drobny, G. P., and Schaefer, J. (2000) Carbon-proton dipolar decoupling in REDOR, J. Magn Reson. 145, 156-158.

98. Jaroniec, C. P., Tounge, B. A., Herzfeld, J., and Griffin, R. G (2001) Frequency selective heteronuclear dipolar recoupling in rotating solids: Accurate ${ }^{13} \mathrm{C}-{ }^{15} \mathrm{~N}$ distance measurements in uniformly ${ }^{13} \mathrm{C},{ }^{15} \mathrm{~N}$-labeled peptides, J. Am. Chem. Soc. 123, 35073519.

99. Kameda, T., Zhao, C. H., Ashida, J., and Asakura, T. (2003) Determination of distance of intramolecular hydrogen bonding in (Ala-Gly) ${ }_{15}$ with silk I form after removal of the effect of MAS frequency in REDOR experiment, J. Magn. Reson. 160, 91-96.

100. Gullion, T., and Vega, S. (1992) A simple magic angle spinning NMR experiment for the dephasing of rotational echoes of dipolar coupled homonuclear spin pairs, Chem. Phys. Lett. 194, 423428.

101. Bennett, A. E., Ok, J. H., Griffin, R. G., and Vega, S. (1992) Chemical-shift correlation spectroscopy in rotating solids-radio frequency-driven dipolar recoupling and longitudinal exchange, J. Chem. Phys. 96, 8624-8627.

102. Bennett, A. E., Rienstra, C. M., Griffiths, J. M., Zhen, W. G., Lansbury, P. T., and Griffin, R. G. (1998) Homonuclear radio frequency-driven recoupling in rotating solids, J. Chem. Phys. 108 , 9463-9479.

103. Suarez, T., Gomara, M. J., Goni, F. M., Mingarro, I., Muga, A. Perez-Paya, E., and Nieva, J. L. (2003) Calcium-dependent conformational changes of membrane-bound Ebola fusion peptide drive vesicle fusion, FEBS Lett. 535, 23-28.

104. Kim, C. H., Macosko, J. C., Yu, Y. G., and Shin, Y. K. (1996) On the dynamics and confirmation of the HA2 domain of the influenza virus hemagglutinin, Biochemistry 35, 5359-5365.

105. Kim, C. H., Macosko, J. C., and Shin, Y. K. (1998) The mechanism for low-pH-induced clustering of phospholipid vesicles carrying the HA2 ectodomain of influenza hemagglutinin, Biochemistry 37, 137-144.

106. Leikina, E., LeDuc, D. L., Macosko, J. C., Epand, R., Shin, Y. K., and Chernomordik, L. V. (2001) The 1-127 HA2 construct of influenza virus hemagglutinin induces cell-cell hemifusion, Biochemistry 40, 8378-8386.

107. Epand, R. F., Yip, C. M., Chernomordik, L. V., LeDuc, D. L., Shin, Y. K., and Epand, R. M. (2001) Self-assembly of influenza hemagglutinin: studies of ectodomain aggregation by in situ atomic force microscopy, Biochim. Biophys. Acta 1513, 167175.

108. Lansbury, P. T., Jr., Costa, P. R., Griffiths, J. M., Simon, E. J., Auger, M., Halverson, K. J., Kocisko, D. A., Hendsch, Z. S., Ashburn, T. T., Spencer, R. G., Tidor, B., and Griffin, R. G. (1995) Structural model for the $\beta$-amyloid fibril based on interstrand alignment of an antiparallel-sheet comprising a C-terminal peptide, Nat. Struct. Biol. 2, 990-998.

109. Benzinger, T. L., Gregory, D. M., Burkoth, T. S., Miller-Auer, H. Lynn, D. G., Botto, R. E., and Meredith, S. C. (1998) Propagating structure of Alzheimer's $\beta$-amyloid(10-35) is parallel beta-sheet with residues in exact register, Proc. Natl. Acad. Sci. U.S.A. 95, 13407-13412.

110. Antzutkin, O. N., Balbach, J. J., Leapman, R. D., Rizzo, N. W., Reed, J., and Tycko, R. (2000) Multiple quantum solid-state NMR indicates a parallel, not antiparallel, organization of beta-sheets in Alzheimer's $\beta$-amyloid fibrils, Proc. Natl. Acad. Sci. U.S.A. 97, 13045-13050.

111. Saez-Cirion, A., and Nieva, J. L. (2002) Conformational transitions of membrane-bound HIV-1 fusion peptide, Biochim. Biophys. Acta $1564,57-65$

112. Haque, M. E., and Lentz, B. R. (2002) Influence of gp4l fusion peptide on the kinetics of poly(ethylene glycol)-mediated model membrane fusion, Biochemistry 41, 10866-10876.

BI0348157 